\title{
Faunal Assemblage Structure Suggests a Limited Impact of the Introduction of Domestic Stock on Later Stone Age Subsistence Economies in South Africa
}

\author{
G. L. Dusseldorp
}

Published online: 15 September 2016

(C) The Author(s) 2016. This article is published with open access at Springerlink.com

\begin{abstract}
Livestock remains appear in the South African archaeological record around 2100 years ago. However, the economic importance of domestic animals in Later Stone Age subsistence is debated. This paper adopts an approach rooted in Optimal Foraging Theory to examine if the introduction of livestock is reflected in changing taxonomic diversity of faunal assemblages. Based on the analysis of a database of $300+$ faunal assemblages, it is concluded that the economic importance of livestock during the final Later Stone Age of South Africa was relatively limited.
\end{abstract}

Résumé Les restes des animaux domestiques apparaissent dans des assemblages fauniques en Afrique du Sud à partir d'il y a 2100 ans. Le rôle du bétail dans les stratégies de subsistance des chasseurscueilleurs des «Later Stone Age » ne sont pas bien compris. Ici, j'adopte l'approche « Optimal Foraging Strategy » pour examiner comment l'adoption du gibier influence l'exploitation des animaux sauvages.

Electronic supplementary material The online version of this article (doi:10.1007/s10437-016-9229-8) contains supplementary material, which is available to authorized users.

\section{G. L. Dusseldorp $(\bowtie)$}

Centre for Anthropological Research, University of Johannesburg, House 5, Bunting Road Campus, PO Box 524, Auckland Park 2006, South Africa

e-mail: g.dusseldorp@gmail.com

\section{G. L. Dusseldorp}

Faculty of Archaeology, Leiden University, PO Box 9514, 2300 RA Leiden, the Netherlands
J'examine le diversité taxonomique de 300+ assemblages faunique accumulés avant et après l'introduction de bétail. Il n’y a pas des changes significantes dans la diversité des espèces répresentées. Cela indique que l'importance economique des animaux domestiques était faible.

Keywords South Africa · Later Stone Age · Pastoralism . Herding $\cdot$ Hunter-gatherers · Optimal Foraging Theory

\section{Introduction}

Livestock was introduced into Later Stone Age (LSA) societies in Southern Africa around 2100 bp (Robbins et al. 2005; Smith 2008; Pleurdeau et al. 2012). However, the role of livestock in LSA subsistence strategies is unclear. Some researchers suggest that livestock keeping spread to South Africa mainly via diffusion and was adopted by indigenous hunter-gatherer groups. This led to the formation of groups of hunters-with-sheep in the western part of southern Africa (e.g., Sadr 2003, 2015). Others argue that herding knowledge and the ideological system necessary to successfully tend livestock preclude sheep herding being taken up easily by local hunter-gatherers. It is therefore argued that groups of pastoralists migrated into South Africa with herds of livestock (e.g., Smith 2008, 2014).

The economic importance of sheep can be underestimated based on their representation in archaeological bone assemblages. The exploitation of herds for dairy products, as practised by the historically known 
Khoe (e.g., Klein 1986; Sealy 2010; Lombard and Parsons 2015), may not be clearly reflected in bone assemblages. After all, the caloric contribution to the human diet of an animal exploited for dairy may far outweigh that of an animal exploited for its meat only, while an equal number of bones ends up in the archaeological record. Furthermore, it has been suggested that herding groups may be largely invisible archaeologically because they practised strategies of high residential mobility, did not repeatedly occupy the same places and did not occupy the contexts, such as rockshelters, upon which archaeological research centres (Arthur 2008; Smith 2008). Finally, some cultural practices may diminish the visibility of livestock exploitation. Livestock bones may have been removed from archaeological sites to prevent the spread of disease in herds for example (Sadr 2008).

However, the economic importance of livestock is expected to be reflected in other aspects of the subsistence economy. I adopt an Optimal Foraging Perspective to examine the influence that the introduction of livestock exerts on the exploitation of other mammal fauna as reflected in changes in the diversity of bone assemblages. I compare the influence of the introduction of livestock with the effects of differing reliability and abundance of animal resources as a result of environmental circumstances. Coastal areas are characterised by rich and reliable shellfish and marine mammal resources (Jerardino 2010; Marean 2010; Dusseldorp and Langejans 2013; Johnson 2014; Kyriacou et al. 2014). I therefore also compare the impact of domestic stock for near-coastal and inland sites separately. The results suggest that the introduction of livestock into LSA societies had limited impact on the exploitation of other mammalian fauna and that environmental settings influenced LSA prey choice more.

\section{An OFT Perspective on the Impact of Food Production}

The introduction of livestock added the potential to practise herding strategies in addition to hunting and gathering. From an economic point of view, if the return rate of herding is higher than that of traditional subsistence activities, it should be adopted (cf. Gremillion 1996). However, the total time budget for subsistence activities is limited. With the introduction of livestock, time had to be allocated to herding at the expense of subsistence activities with lower return rates (cf. Winterhalder 1987; Alvard and Kuznar 2001).

Optimal Foraging Perspective (OFT) has been criticised by various scholars (e.g., Ingold 2000; Twiss 2012; Zeder 2012) for oversimplifying foragers' subsistence decisions. Some of the assumptions of OFT are argued to be unrealistic, such as the tenet that foraging strategies indeed will be organised optimally. In many groups, cultural factors such as food taboos, or the taste of food, will lead to foraging choices that are said to be calorically suboptimal. This does not mean that OFT models are not useful. They help frame explicitly which resources we expect hunter-gatherers to exploit in a given situation, which then signals deviations of economically expected patterns (Kelly 1995). Also, in some cases other commodities such as animal fur or prestige are the goal of foraging, not calories per se. These factors can be taken into account in OFT models, which rely on a currency that foragers are assumed to maximise. The currency can take into account the importance of non-caloric factors in foraging decisions (e.g., Winterhalder 1987; Jones 2004; McGuire and Hildebrandt 2005; Dusseldorp 2012a). As I am not using OFT to predict what specific species should be exploited, but only to understand general changes in faunal assemblage structure, the possibility that foraging need not have been organised optimally does not affect this analysis. The only assumption relied on here is that the total amount of time any individual spent on subsistence activities was constrained. The addition of new subsistence activities such as herding would then lead to a decrease in time spent on other such activities.

I assume that the introduction of livestock affects the time and effort expended on hunting most drastically, because the introduction of sheep and cattle adds a prey type. The prey choice model predicts that foragers will preferentially exploit those prey types that provide the highest return rate: the yield of the prey, expressed in a currency, minus its search and handling costs (e.g., MacArthur and Pianka 1966; Winterhalder 1987, 2001; Dusseldorp 2012a). Hunter-gatherers generally exploit a set of relatively high-ranked prey types and ignore species with low yields. The introduction of domestic animals adds a new option to the mix. Herding demands a lot of effort that cannot be spent on other subsistence activities (e.g., Yellen 1984), which is expected to result in a narrowing of the diet breadth. In the new situation, instead of exploiting lower-ranking 
prey types, time could be spent more productively on herding activities. It is likely that the reduced amount of time spent on hunting would be concentrated on exploiting preferred (for whatever reason) species.

In historical accounts of Khoe herding societies observed by Europeans, a large importance of dairy products is attested (Smith and Webley 2000; Lombard and Parsons 2015). However, even though an emphasis on dairy products may not be directly reflected in bone assemblages, the contribution of these products affects the trade-off between investments in different subsistence activities. In the case of animal husbandry for meat only, modelling has been used to suggest that only animals exceeding $40 \mathrm{~kg}$ should be hunted (Alvard and Kuznar 2001). If exploitation of milk was practised, this threshold would be higher and might result in exclusively agricultural subsistence strategies (Alvard and Kuznar 2001). This suggests that even if remains of livestock are underrepresented in the archaeological record, their economic importance is reflected in the structure of archaeological bone assemblages.

The proposed impact of the introduction of livestock herding on hunting of wild animals is supported by the widespread division of labour between men and women (Murdock and Provost 1973; Marlowe 2007). Among hunter-gatherers, men are almost universally responsible for hunting large game, while women perform most gathering tasks. This division of labour is by no means absolute, however. Men also perform collection activities; as one example, the presence of "surfer's ear" in a male hunter-gatherer skeleton suggests that men may have regularly collected marine foods in the sea (Morris et al. 2014). Division of labour is less clear-cut among pastoralists. Among the Khoekhoen, it appears that men were generally concerned with herding. However, they would leave these activities to women for days on end in order to go hunting (Smith and Webley 2000).

\section{Materials and Methods}

I compiled a database of published Late Stone Age (LSA) macromammal faunal assemblages, listed in the Supplementary Data Table 1. I have excluded Pleistocene and Early Holocene assemblages to ensure equivalence of environmental circumstances during the deposition of the assemblages. The Early-Middle Holocene boundary is dated to $8.2 \mathrm{ka}$ (Walker et al. 2012), temporally close to the transition between
Oakhurst and Wilton industries, around $8 \mathrm{ka}$ (Lombard et al. 2012). Therefore, Oakhurst and earlier assemblages were excluded, and Wilton and younger assemblages were included in the database. I have omitted assemblages where the original excavation or faunal reports suggest important non-human impact on the faunal assemblage.

I compared assemblages with no domestic remains with those assemblages with domestic remains. This division may be too simplistic, since hunter-gatherers will have occasionally acquired livestock through trade/ exchange or theft (Smith 2008). However, distinguishing between hunter-gatherer and herder sites based on their material remains has proved challenging, and no criteria are currently generally accepted (Smith et al. 1991; Sadr et al. 2003; Arthur 2008; Sadr 2009; Orton 2012). Moreover, the acquisition of foodstuffs through trade or theft would also be expected to be reflected in hunter-gatherer subsistence strategies (cf. Wilkie and Curran 1993). I have excluded a singlespecies kill site, SK 400 (Dewar et al. 2006), from the comparisons, because it inordinately influenced the slope of the regression line for assemblages without domestic remains. Similarly, I excluded specialist pastoralist assemblages from Jakkalsberg (Brink and Webley 1996) from the comparisons. I also compared coastal assemblages (located $<10 \mathrm{~km}$ from the coast) with non-coastal assemblages, to check how the availability of marine resources influenced foraging strategies.

I examined the richness of the different groups by recording the identified number of non-overlapping mammal taxa (NTAXA) (cf. Grayson 1991). Elements not determined to species level were only counted as representing a taxon if no elements from a species within the category were present. For example, Raphicerus sp. was counted as a represented taxon only if no elements determined to either steenbok (Raphicerus campestris) or grysbok (Raphicerus melanotis) were reported. I excluded Homo from NTAXA in assemblages where it was present. The representation of non-mammalian species is not always reported in detail, so it could not be incorporated in the analysis. This is unfortunate, as some sites were occupied specifically to exploit non-mammal taxa, for example megamidden sites on the coast (e.g., Jerardino 2012), but also inland, such as Likoaeng which appears to have been occupied to target fish spawning runs (Plug et al. 2010). I have assumed that when large mammals were exploited at such locations, prey choice would be 
Table $1 r^{2}$ values of the regression analyses for the datasets of assemblages with and without remains of domestic animals

\begin{tabular}{lll}
\hline Dataset & $r^{2}$ & $p$ value \\
\hline $\log \Sigma$ NISP, domestic animals present & 0.288 & $p<0.01$ \\
$\log \Sigma$ NISP, domestic animals absent & 0.503 & $p<0.01$ \\
$\log \Sigma \mathrm{MNI}$, domestic animals present & 0.533 & $p<0.01$ \\
$\log \Sigma \mathrm{MNI}$, domestic animals absent & 0.56 & $p<0.01$ \\
\hline
\end{tabular}

similar to locations where alternative resources were less important.

Unfortunately, faunal remains are often not preserved in open-air sites. This means that the dataset consists overwhelmingly of rockshelter sites, which may have played a different role in LSA settlement systems (cf. Plug 1997). This problem may be exacerbated by the fact that herding societies may have used rockshelters less frequently than did hunter-gatherer societies (Smith 2008). I have also compared only the open-air subsets of the dataset to attempt to deal with this.

To control for the effects of sample size, I plotted NTAXA against the log of the total assemblage size (in terms of number of identified specimens, $\log \Sigma$ NISP, and minimum number of individuals, $\log \Sigma \mathrm{MNI}$ ). This can be used as a measure of the diversity of exploited resources represented (Lyman 2008, 2015). Although the number of represented mammal taxa in a faunal assemblage depends on sample size, other variables influence it too. The diet breadth of the group accumulating faunal assemblages and the taxonomic richness in the environment also influence how many taxa end up in faunal assemblage (Lyman 2015). Regression analyses were conducted on different groupings of sites. This procedure allows an appreciation of how the number of species present in assemblages is expected to increase with increasing sample size. $t$-Tests were used to assess whether the slopes of the regression lines of different groups of assemblages differ significantly (cf. Faith 2008); if they do, this is taken to signal a differing diversity of exploited prey between the groups of sites (cf. Grayson and Delpech 1998; Faith 2008; Dusseldorp 2012b). Similar comparisons have been applied to, for example, the study of prehistoric foraging strategies in Late Pleistocene and Holocene southern Africa and the Upper Palaeolithic of Europe (Grayson and Delpech 1998; Faith 2011, 2013).

I also examined the Shannon-Wiener index of heterogeneity $(H)$ and the Shannon index of evenness $(e)$ for the assemblages (Lyman 2008, pp. 192-198). H measures assemblage heterogeneity, comprising both species richness and evenness (Lyman 2008). $H$ is calculated as follows: $H=-\sum P_{i}\left(\ln P_{1}\right)$, where $P_{i}$ is the proportion of taxon $i$ in the assemblage. This gives a number between 1.5 and 3.5. The higher the number, the greater assemblage heterogeneity. I calculated $e$, derived from $H$, to quantify assemblage evenness: $e=H / \ln S$,

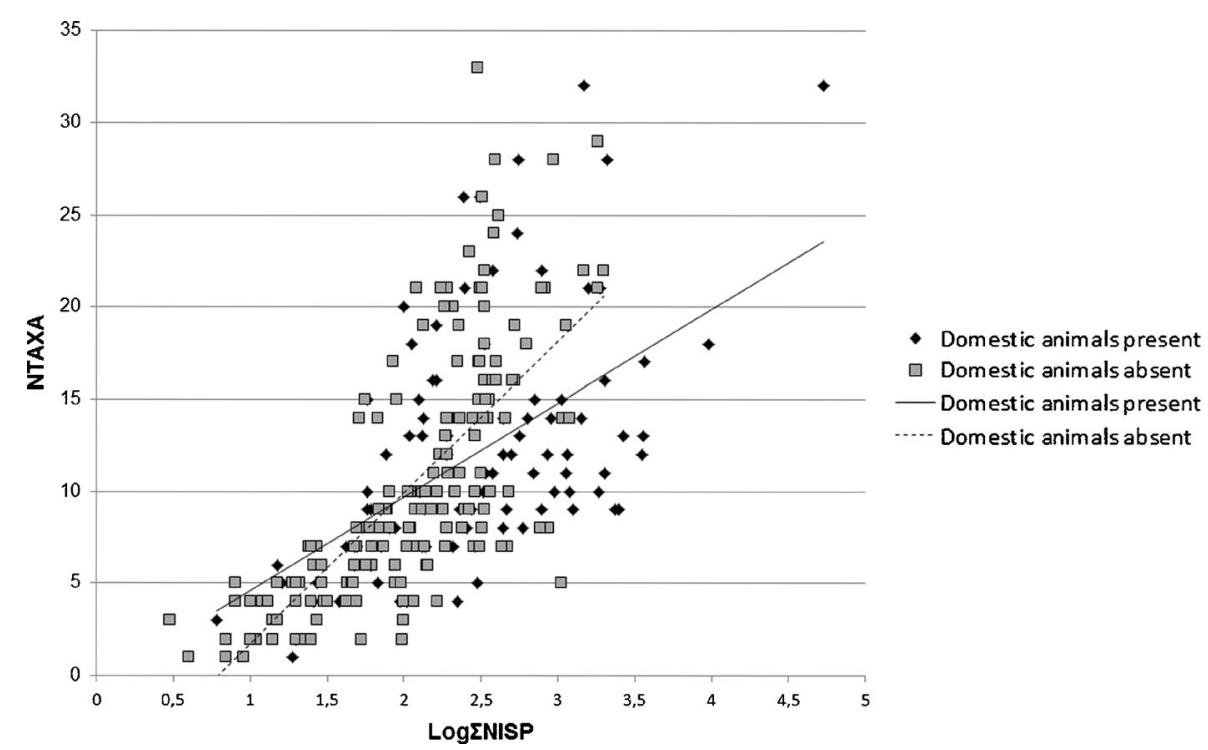

Fig. 1 Scatterplot of $\log \Sigma$ NISP and NTAXA of assemblages with and without remains of domestic animals 


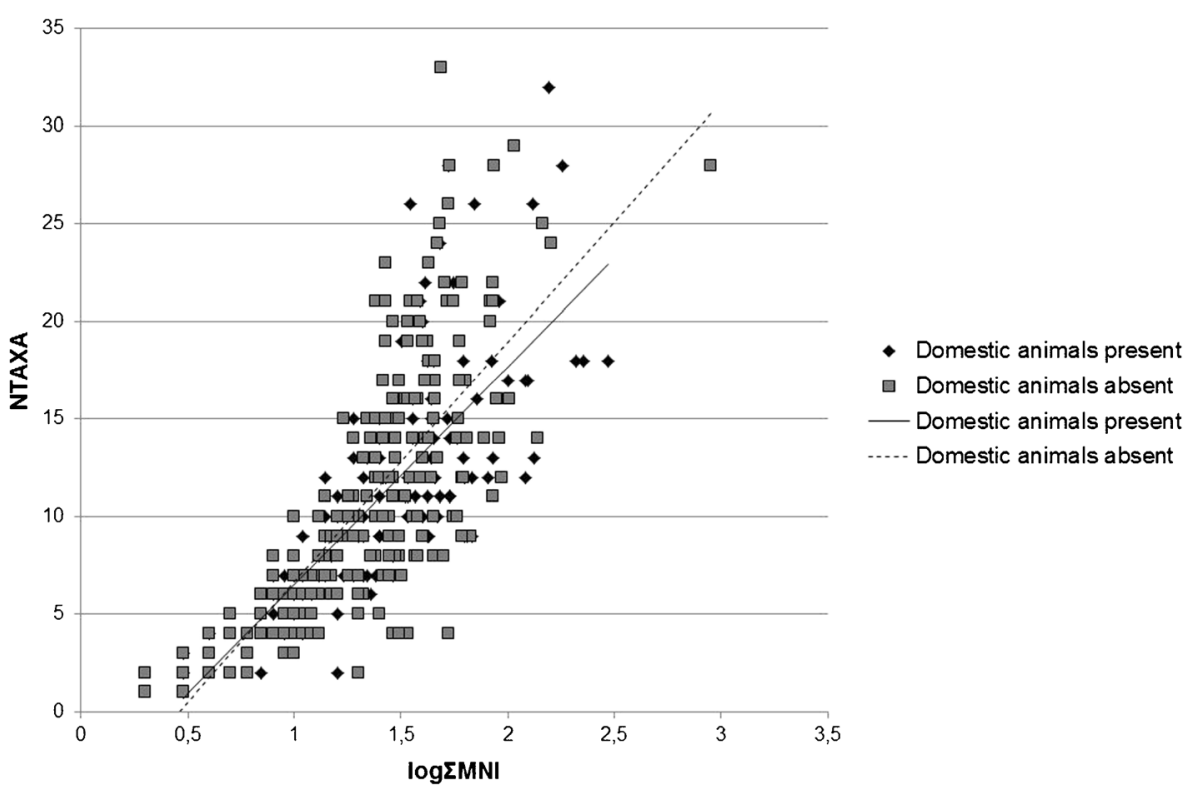

Fig. 2 Scatterplot of $\log \Sigma M N I$ and NTAXA of assemblages with and without remains of domestic animals

where $S$ stands for NTAXA in the assemblage. This yields a value between 0 and 1 , where 1 signifies an assemblage where each taxon accounts for the same proportion of the assemblage and values closer to 0 signify assemblages where a limited number of taxa are much better represented than the rest (Lyman 2008). I calculated these based on NISP and MNI. Although the suitability of MNI for such calculations is contested because it is a derived index (Plug and Plug 1990; see also Lyman 2008), it has also been argued to be one of the most reliable ways of estimating the abundance of different taxa in faunal assemblages (Domínguez-Rodrigo 2012).

The Shannon-Wiener index of heterogeneity controls for the effects of sample size by focussing on the proportion of each represented taxon of the total NISP/MNI (but see Cruz-Uribe 1988; Meltzer et al. 1992). Because of this, bones identified to broad categories such as genus cannot be included in these calculations, leading to smaller $\Sigma$ NISP/MNI figures. If prey choice was more selective following the introduction of livestock, assemblages are expected to be characterised by lower $H$ and $e$ values (cf. Dusseldorp 2012b).

Statistical analysis was conducted to establish if $H$ and $e$ differed by the groups of interest. Univariate analysis of the dependent variables $H$ and $e$ indicated these measures were not normally distributed. For this reason, both non-parametric (Kruskal-Wallis test) and equivalent parametric tests (one-way ANOVA) were performed to compare mean rank or mean scores respectively, of $H$ and $e$ for the four groups. For the nonparametric analysis, Mann-Whitney tests with Bonferroni adjustment were used for post hoc comparisons. For parametric analysis, the Levene's test for homogeneity of variance indicated that the assumption of equal variance for groups was violated, so the Tamhane test was used for post hoc comparisons (Personal communication, R. Devey 2015). The nonparametric and parametric tests yielded similar results, so only the parametric test results are reported here.

\section{Results}

A comparison of assemblages with and without remains of domestic animals shows that in both sets of assem-

Table 2 Results of statistical comparisons of the slopes of the regression lines through the datasets with and without remains of domestic animals

\begin{tabular}{|c|c|c|c|c|}
\hline Comparison & Slope 1 & Slope 2 & Significant & $p$ value \\
\hline $\begin{array}{l}\log \Sigma \text { NISP domestic } \\
\text { animals present } \\
\text { vs. absent }\end{array}$ & 5.079 & 8.257 & Yes & 0.002 \\
\hline $\begin{array}{l}\log \Sigma \mathrm{MNI} \text { domestic } \\
\text { animals present } \\
\text { vs. absent }\end{array}$ & 11.112 & 12.273 & No & 0.325 \\
\hline
\end{tabular}


Table $3 r^{2}$ values of the regression analyses for the datasets of coastal and inland assemblages

\begin{tabular}{lll}
\hline Dataset & $r^{2}$ & $p$ value \\
\hline $\log \Sigma$ NISP coastal sites & 0.626 & $p<0.01$ \\
$\log \Sigma$ NISP inland sites & 0.633 & $p<0.01$ \\
$\log \Sigma$ MNI coastal sites & 0.763 & $p<0.01$ \\
$\log \Sigma$ MNI inland sites & 0.541 & $p<0.01$ \\
\hline
\end{tabular}

blages, $\log \Sigma$ NISP and $\log \Sigma$ MNI are significantly correlated to NTAXA (Table 1). The slope of the regression line of assemblages without remains of domestic animals is steeper than that of the group of assemblages with remains of domestic animals (Figs. 1 and 2). This suggests the exploitation of a less diverse set of prey animals by people with access to livestock. The difference between the slopes of the regression lines through the groups is statistically significant when comparing NTAXA to $\log \Sigma$ NISP, but not significant when comparing NTAXA to $\log \Sigma \mathrm{MNI}$ (Table 2). It is not immediately clear whether the $\log \Sigma$ NISP or the $\log \Sigma \mathrm{MNI}$ data are more reliable, so I tested to see whether other factors better explain the differences in the structure of faunal assemblages.

An influential factor in prey choice is the availability of marine resources, which provide a very reliable source of protein-rich food (Jerardino 2010; Marean 2010; Dusseldorp and Langejans 2013; Johnson 2014; Kyriacou et al. 2014). Hence, I separated the sites into coastal ( $\leq 10 \mathrm{~km}$ from the coast) and inland categories (Supplementary Data Table 2). Regression analyses of the latter groupings yield higher $r^{2}$ values than grouping the sites according to the presence or absence of domestic animal remains (Table 3, Figs. 3 and 4). This suggests that proximity to the coast explains a larger proportion of the variability in the datasets than the presence or absence of domestic animal remains. Moreover, the differences between the slopes of the regression lines of the groups of coastal and inland sites differ significantly for both $\log \Sigma$ NISP and $\log \Sigma \mathrm{MNI}$ (Table 4). This demonstrates that LSA inhabitants of coastal areas exploited a significantly narrower set of mammals than did inhabitants of inland areas.

The difference between the slopes of the regression lines through the assemblages with, and those without remains of domestic animals, although insignificant for the $\log \Sigma \mathrm{MNI}$ comparison, suggests that the availability of livestock had some effect on prey choice. However, scrutiny of the composition of the dataset suggests that the difference may also be caused by the fact that the group of assemblages with remains of domestic animals is dominated by coastal sites (Table 5). The group of assemblages without remains of domestic animals, on the other hand, contains mostly inland sites (Table 5).

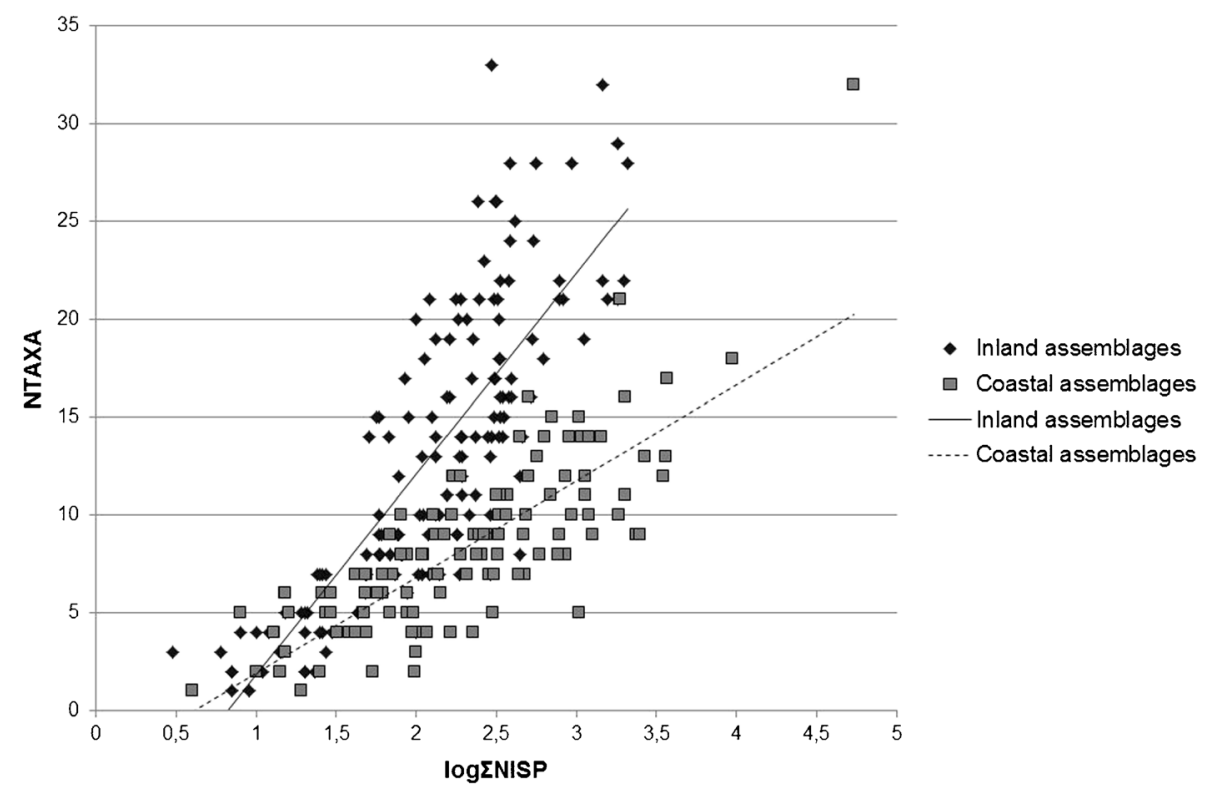

Fig. 3 Scatterplot of $\log \Sigma$ NISP and NTAXA for coastal and inland assemblages 


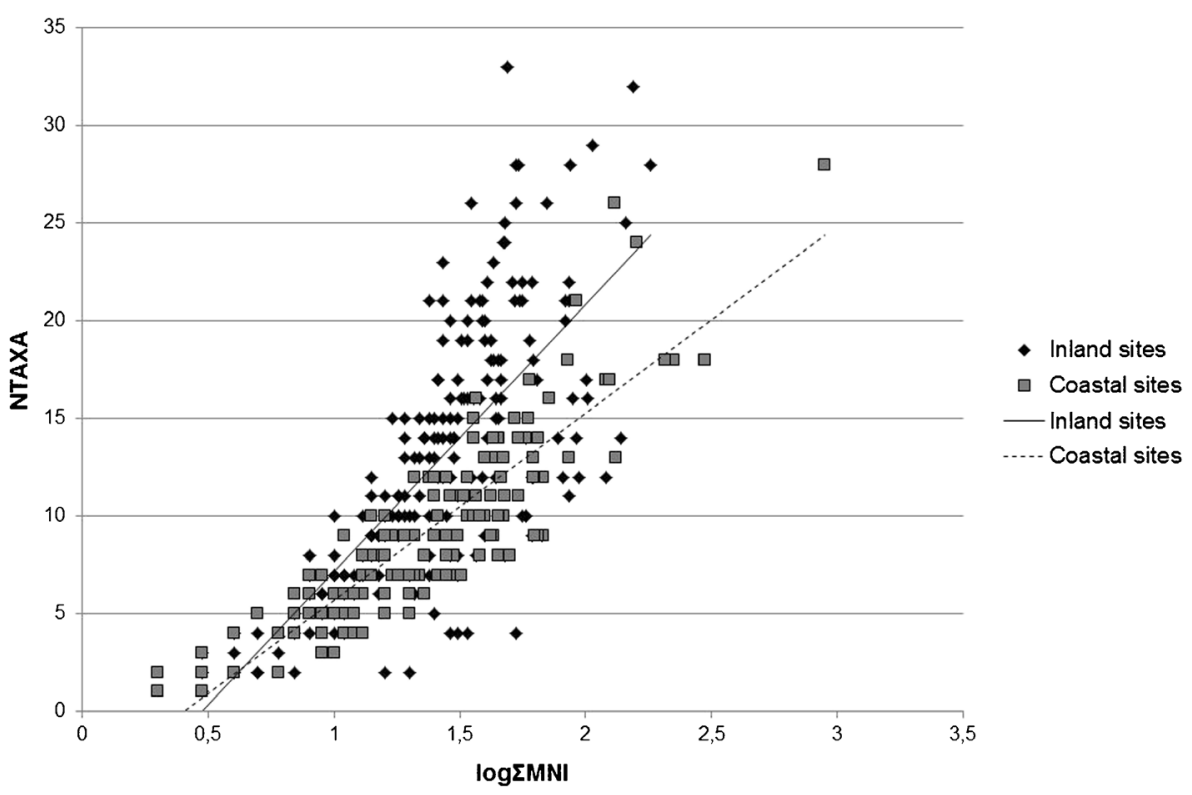

Fig. 4 Scatterplot of $\log \Sigma \mathrm{MNI}$ and NTAXA for coastal and inland assemblages

To further investigate if the introduction of domestic animals influenced prey choice, or whether the sampling of coastal and inland sites explains the difference between the slope of regression lines through the group of assemblages with and without domestic animals, I looked at the influence of domestic animals within the inland and coastal datasets. A comparison within the latter datasets of the influence of the presence of domestic animals shows that here, the slopes of regression lines of the datasets are very similar (Figs. 5 and 6). $t$ Tests show that the differences between the slopes of the regression lines are not significant (Table 6). This means that the richness of coastal assemblages is comparable, regardless of whether domestic animals were present. This also appears to be the case inland. Also, I compared the relationship between $\log \Sigma \mathrm{NISP} / \log \Sigma \mathrm{MNI}$ and NTAXA of inland assemblages with remains of domestic animals with that of coastal assemblages with remains of domestic animals (Fig. 7). Finally, I compared

Table 4 Results of statistical comparisons of the slopes of the regression lines through the inland and coastal datasets

\begin{tabular}{lllll}
\hline Comparison & Slope 1 & Slope 2 & Significant & $p$ value \\
\hline $\begin{array}{l}\log \Sigma \text { NISP coastal } \\
\text { vs. inland }\end{array}$ & 4.939 & 10.19 & Yes & $p<0.01$ \\
$\begin{array}{l}\log \Sigma \text { MNI coastal } \\
\text { vs. inland }\end{array}$ & 9.564 & 13.673 & Yes & $\mathrm{p}<0.01$ \\
\hline
\end{tabular}

inland assemblages without remains of domestic animals, with coastal assemblages without remains of domestic animals (Fig. 8). $t$-Tests show that in these comparisons, the difference between the slopes for the datasets is statistically significant (Table 7).

Environmental change, or environmental degradation as a result of (over)grazing, may result in changes in prey availability. To test whether this influenced prey choice, I divided the assemblages without remains of domestic animals where I could track down radiocarbon dates, into two groups: those older than, and younger than, $2000 \mathrm{bp}$ (Supplementary Data Table 3). I removed Die Kelders from the coastal NISP-set as there is the possibility of mixing of assemblages with and without domesticates here. Comparison of the assemblages with remains of domestic animals, with those without remains of domestic animals older than $2000 \mathrm{bp}$, shows no significant differences. Similarly, comparison of assemblages with

Table 5 Representation of coastal and inland sites in the datasets of sites with domestic animals and sites without domestic animals

NISP dataset MNI dataset

\begin{tabular}{llll}
\hline Domestic animals present & Coastal & $59 \%$ & $63 \%$ \\
& Inland & $41 \%$ & $37 \%$ \\
Domestic animals absent & Coastal & $36 \%$ & $27 \%$ \\
& Inland & $64 \%$ & $73 \%$ \\
\hline
\end{tabular}




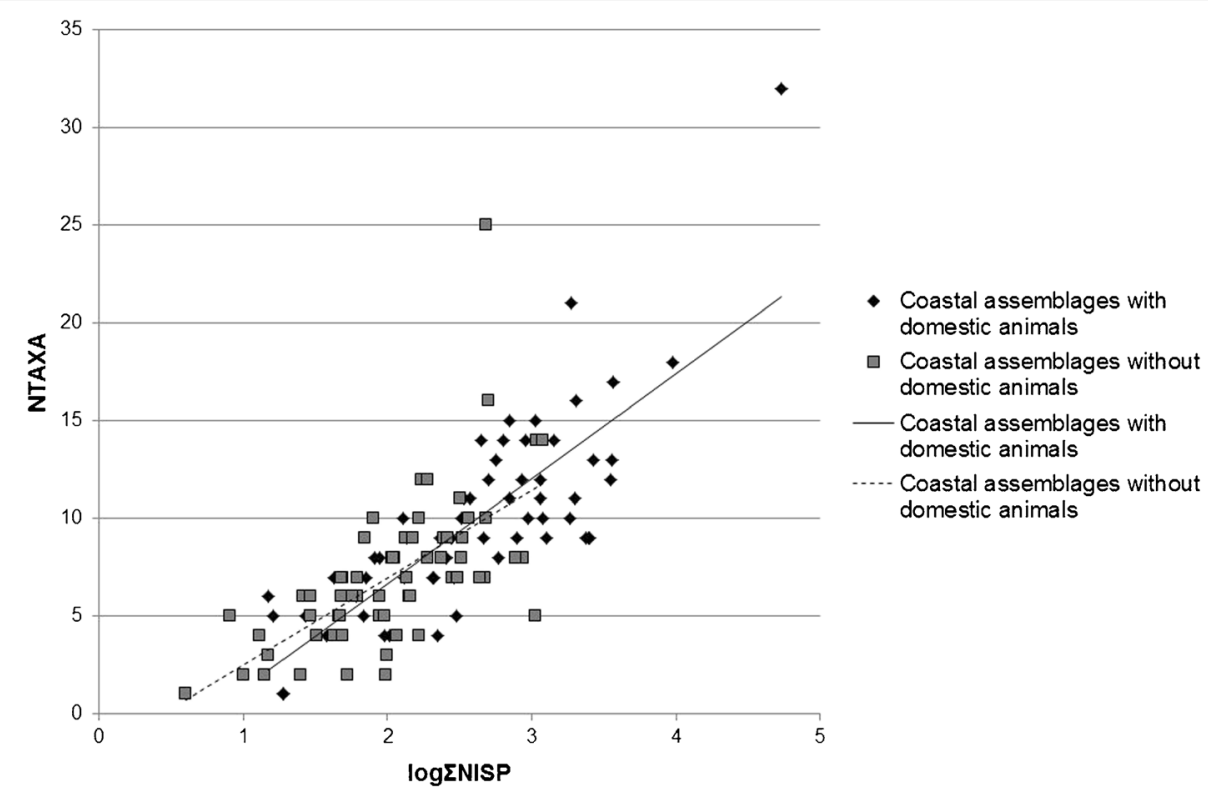

Fig. 5 Scatterplot of $\log$ NNISP and NTAXA of coastal assemblages with and without remains of domestic animals

domestic remains with assemblages without domestic remains younger than $2000 \mathrm{bp}$ yields no significant differences (Table 8). This suggests that the comparisons are not unduly influenced by environmental changes taking place during the Middle and Late Holocene.

The dataset is heavily dominated by cave and rockshelter sites (Table 5). This is unfortunate, as it may entail an underrepresentation of pastoralist sites (Arthur 2008; Smith 2008). Also, cave and rockshelter sites may have been used as roosting locations by raptors or as carnivore dens, so that multiple accumulating agents may be represented, despite efforts to include only human-accumulated assemblages in the database. I have therefore also compared the richness of open-air sites with and without domestic animals to determine the reliability of the patterns sketched above (Table 9). A comparison of the entire sample of open-air sites shows that no significant difference is apparent in the

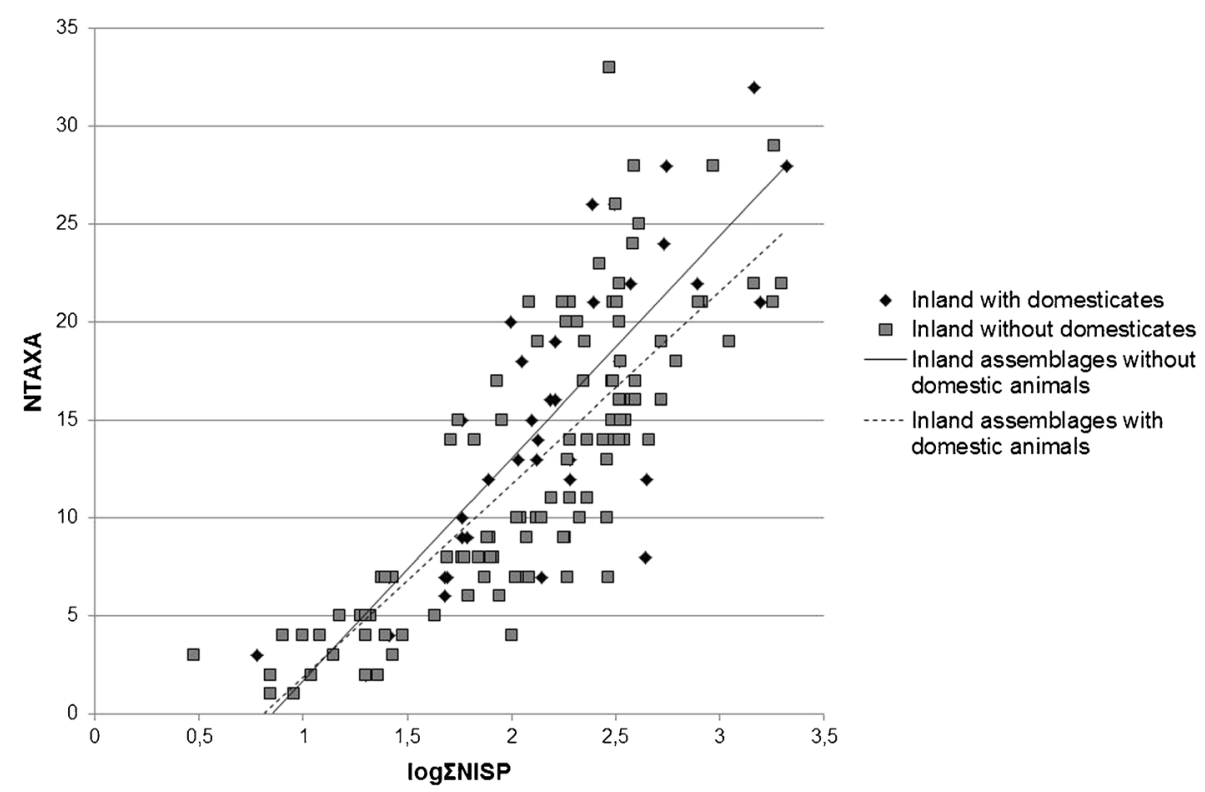

Fig. 6 Scatterplot of $\log \Sigma$ NISP and NTAXA of inland assemblages with and without remains of domestic animals 
Table 6 Results of statistical comparisons of the slopes of the regression lines through the inland datasets with and without remains of domestic animals and coastal datasets with and without remains of domestic animals

\begin{tabular}{lrrrc}
\hline Comparison & Slope 1 & Slope 2 & Significant & $p$ value \\
\hline $\log \Sigma$ NISP coast domesticates present vs. absent & 5.373 & 3.938 & No & 0.07 \\
$\log \Sigma$ MNI coast domesticates present vs. absent & 9.334 & 9.866 & No & 0.557 \\
$\log \Sigma$ NISP inland domesticates present vs. absent & 11.365 & 9.859 & No & 0.334 \\
$\log \Sigma$ MNI inland domesticates present vs. absent & 15.554 & 13.012 & No & 0.211 \\
\hline
\end{tabular}

relationship between NTAXA and $\log \Sigma$ NISP/log $\Sigma$ MNI. This confirms the pattern seen in the dataset as a whole. Unfortunately, the sample of inland open-air sites is too small for meaningful comparisons (eight assemblages with remains of domestic animals and six without; for in some of these assemblages only NISP [Likoaeng] or only MNI [OFD 1] data are available, limiting comparisons even further). Comparison of only open-air coastal sites with and without remains of domestic animals shows no significant difference in the slope of the regression lines, as expected in view of the patterns described above. As far as the data allow examination, this suggests that the abundance of rockshelters does not unduly affect the outcomes of the analysis.

Finally, the $H$ and $e$ values were calculated for the assemblages based on both NISP and MNI. I compared the average values of the assemblages divided into four groups: inland with remains of domestic animals, inland without remains of domestic animals, coastal with remains of domestic animals, and coastal without remains of domestic animals. A one-way ANOVA test shows that significant differences exist between the mean values of both $H$ and $e$ between the different groups (Tables 10 and 13). Tamhane post hoc comparisons between the different pairs of groups show that the $H$ values of both coastal groups do not differ significantly from each other. Similarly, the values of both inland groups do not differ significantly from each other (Tables 11 and 14). The heterogeneity of both groups of coastal assemblages does differ significantly from that of both groups of inland assemblages (Tables 11 and 14; Figs. 9 and 12).

The results of the Tamhane post hoc comparisons for evenness values show a more complex picture. The values calculated from NISP show that the group of coastal assemblages where remains of domestic animals are present differs significantly from all others (Table 12). The evenness of coastal assemblages without remains of domestic animals appears to occupy an intermediate position between coastal and inland assemblages with

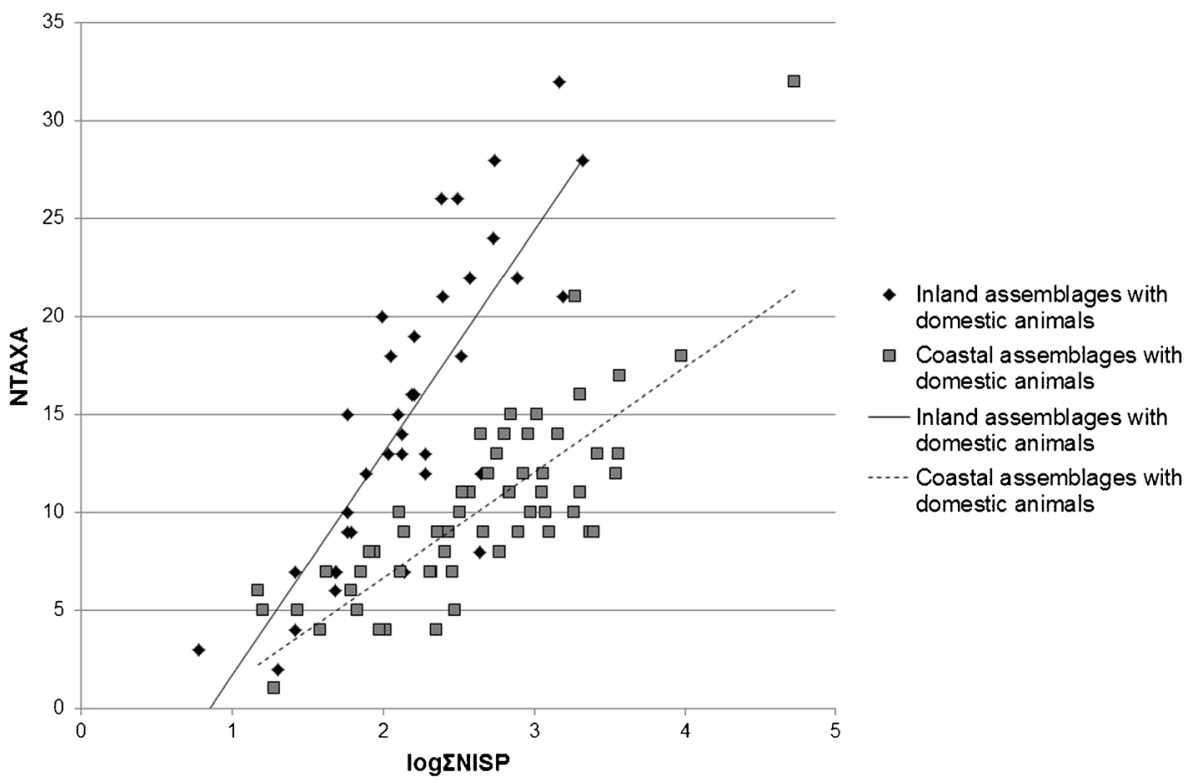

Fig. 7 Scatterplot of $\log \Sigma$ NISP and NTAXA of coastal and inland assemblages with domesticates 


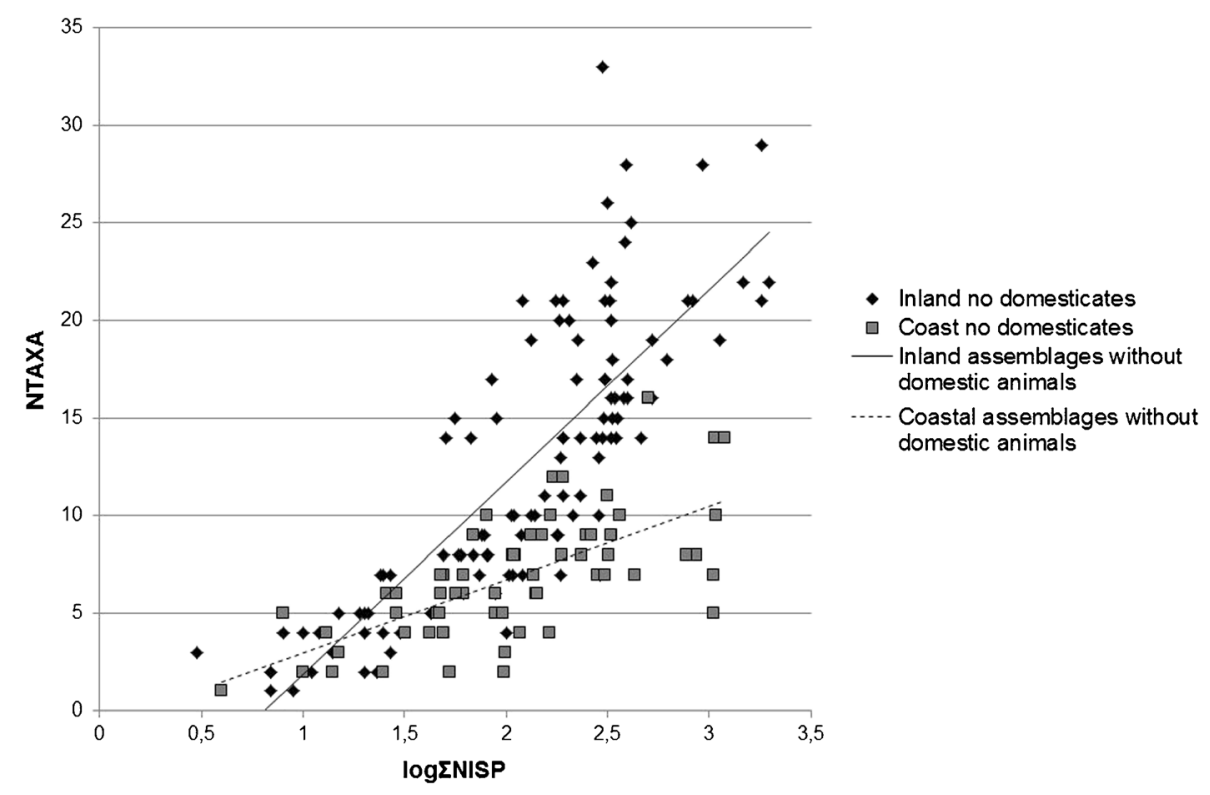

Fig. 8 Scatterplot of $\log \Sigma$ NISP and NTAXA of coastal and inland assemblages without domesticates

remains of domestic animals (Fig. 10). However, statistically the evenness of coastal assemblages without remains of domestic animals also differs significantly from all others (Fig. 11). The inland assemblages with and without remains of domestic animals do not differ significantly from each other (Table 12). The MNI results confirm the significant difference of the coastal assemblages with remains of domestic animals from both groups of inland assemblages (Table 15). It also confirms the intermediate position of coastal assemblages without remains of domestic animals (Tables 13 and 14). The difference between coastal assemblages without remains of domestic animals and all others is no longer significant (Table 15). The use of MNI results in higher evenness values, because it inflates the importance of rare taxa in assemblages (see Fig. 12) (Lyman 2008). This may explain the smaller amount of significant differences in this comparison.

\section{Discussion}

The comparison of the different groups of assemblages suggests that the economic impact of the introduction of livestock into LSA subsistence strategies was relatively small. The significant difference in the slope of the regression lines through the groups of sites with and without remains of domestic animals is at least partly due to the different representation of coastal and inland sites in the groups. Moreover, the difference between the slopes of regression lines through the groups of coastal and inland sites regardless of the presence of domestic animals is larger. This is combined with higher $r^{2}$ values of the regression analyses, suggesting that this grouping of the assemblages explains a larger amount of the variability in the database. Hence, the distance from a site to the coast appears to explain differences in the structure of faunal assemblages better, likely because the

Table 7 Results of statistical comparisons of the slopes of the regression lines through the inland and coastal datasets with remains of domestic animals and through the inland and coastal datasets without remains of domestic animals

\begin{tabular}{|c|c|c|c|c|}
\hline Comparison & Slope 1 & Slope 2 & Significant & $p$ value \\
\hline $\log \Sigma$ NISP domesticates present coast vs. inland & 5.373 & 11,365 & Yes & $p<0.01$ \\
\hline $\log \Sigma \mathrm{MNI}$ domesticates present coast vs. inland & 9.334 & 15.553 & Yes & $p<0.01$ \\
\hline $\log \Sigma$ NISP domesticates absent coast vs. inland & 3.938 & 9.859 & Yes & $p<0.01$ \\
\hline $\log \Sigma \mathrm{MNI}$ domesticates absent coast vs. inland & 9.866 & 13.012 & Yes & $p<0.01$ \\
\hline
\end{tabular}


Table 8 Results of statistical comparisons of the slopes of the regression lines through the datasets of assemblages with remains of domestic animals and those without remains of domestic animals dated to $>2000$ and $<2000 \mathrm{bp}$

\begin{tabular}{lcccc}
\hline Comparison & Slope 1 & Slope 2 & Significant & $p$ value \\
\hline $\log \Sigma$ NISP domesticates present vs. absent $<2000$ bp coast & 4.456 & 3.363 & No & 0.041 \\
$\log \Sigma$ NISP domesticates present vs. absent $<2000$ bp inland & 11.001 & 8.649 & No & 0.1 \\
$\log \Sigma$ MNI domesticates present vs. absent $<2000$ bp coast & 9.334 & 10.387 & No & No \\
$\log \Sigma$ MNI domesticates present vs. absent $<2000$ bp inland & 15.503 & 11.269 & No & 0.369 \\
$\log \Sigma$ NISP domesticates present vs. $>2000$ bp coast & 4.456 & 4.481 & No & 0.07 \\
$\log \Sigma$ NISP domesticates present vs. $>2000$ bp inland & 11.001 & 10.213 & No & 0.654 \\
$\log \Sigma$ MNI domesticates present vs. $>2000$ bp coast & 9.334 & 9.711 & No & 0.713 \\
$\log \Sigma$ MNI domesticates present vs. $>2000$ bp inland & 15.503 & 13.85 & & 0.458 \\
\hline
\end{tabular}

coast provides a very reliable resource base (Jerardino 2010; Marean 2010; Dusseldorp and Langejans 2013; Johnson 2014; Kyriacou et al. 2014). Similarly, distance to the coast seems to be the main determinant of heterogeneity values.

The NISP-based evenness values do suggest that the introduction of livestock allowed more selective exploitation of resources. This results in a lower evenness of coastal assemblages with remains of domestic animals than of coastal assemblages without remains of domestic animals. Likewise, the evenness of inland assemblages with remains of domestic animals is slightly lower than that of inland assemblages without remains of domestic animals. Coastal assemblages without remains of domestic animals occupy an intermediate position. They are characterised by higher evenness (suggesting less selective prey choice) than coastal assemblages with remains of domestic animals. The MNI evenness figures support the added influence of livestock allowing more selective prey exploitation, showing that coastal assemblages with remains of domestic animals differ significantly from all others, but that coastal assemblages without remains of domestic animals are characterised by a higher evenness that does not differ significantly from that of inland assemblages.

These results suggest that the exploitation of marine resources was of crucial importance to the inhabitants of coastal areas, also after the introduction of livestock. This impression is reinforced by the realisation that the importance of marine mammals is likely underestimated archaeologically (Smith and Kinahan 1984; Kandel and Conard 2003; Smith 2006a), as it is possible to exploit the sculp (skin plus subcutaneous tissue), the calorically richest part of the animal, which does not contain bones (see e.g., Dusseldorp and Langejans 2013).

If LSA foragers aimed to maximise the caloric return of mammal exploitation strategies, the lack of change in the taxonomic diversity of faunal assemblages suggests that the economic importance of herding was small. Until around $1000 \mathrm{bp}$, LSA groups in southern Africa appear to have practised an "extended broad-spectrum" subsistence economy (cf. Louwe Kooijmans 1993). Livestock appears to have been an additional element in the subsistence economy, while hunting and gathering remained important in terms of their caloric distribution to the diet. This importance suggests that the role of secondary

Table 9 Results of statistical comparisons of the slopes of the regression lines through the datasets of coastal open-air sites with and without remains of domestic animals

\begin{tabular}{|c|c|c|c|c|}
\hline Comparison & Slope 1 & Slope 2 & Significant & $p$ value \\
\hline $\begin{array}{l}\log \Sigma \text { NISP all open-air sites with domestic remains of domestic animals } \\
\text { vs. open-air sites without }\end{array}$ & 3.19 & 2.478 & No & 0.621 \\
\hline $\log \Sigma \mathrm{MNI}$ all open-air sites with remains of domestic animals vs. without & 8.529 & 9.722 & No & 0.603 \\
\hline $\log \Sigma$ NISP coastal open-air sites domestic animals present vs. absent & 3.737 & 1.989 & No & 0.154 \\
\hline $\log \Sigma \mathrm{MNI}$ coastal open-air sites domestic animals present vs. absent & 8.91 & 7.31 & No & 0.396 \\
\hline
\end{tabular}


Table 10 Results of the one-way ANOVA comparison of the $H$ and $e$ values based on NISP of the four groups of sites

\begin{tabular}{|c|c|c|c|c|c|c|}
\hline & Number & Mean & Standard deviation & $F$ statistic & Significance & Effect size \\
\hline \multicolumn{7}{|l|}{ Heterogeneity } \\
\hline $\begin{array}{l}\text { Coast domestic animals present } \\
\text { Coast domestic animals absent }\end{array}$ & $\begin{array}{l}57 \\
59\end{array}$ & $\begin{array}{l}1.135 \\
1.262\end{array}$ & $\begin{array}{l}0.38 \\
0.429\end{array}$ & 43.369 & $<0.01$ & 0.336101 \\
\hline Inland domestic animals present & 37 & 1.985 & 0.526 & & & \\
\hline Inland domestic animals absent & 108 & 1.901 & 0.604 & & & \\
\hline \multicolumn{7}{|l|}{ Evenness } \\
\hline $\begin{array}{l}\text { Coast domestic animals present } \\
\text { Coast domestic animals absent }\end{array}$ & $\begin{array}{l}57 \\
59\end{array}$ & $\begin{array}{l}0.529 \\
0.668\end{array}$ & $\begin{array}{l}0.221 \\
0.207\end{array}$ & 29.763 & $<0.01$ & 0.257845 \\
\hline Inland domestic animals present & 37 & 0.779 & 0.128 & & & \\
\hline Inland domestic animals absent & 108 & 0.789 & 0.147 & & & \\
\hline
\end{tabular}

products in addition to meat was insufficient to drastically change the time allocated to foraging. However, from around $\mathrm{AD} 700$, but especially after 1000, specialised pastoralist sites are known. At Kasteelberg A and B, based on detailed archaeozoological analysis, the age distribution of the represented sheep suggests that specialised herd management strategies geared towards maximising meat and potentially milk yield (Klein and Cruz-Uribe 1989). At Jakkalsberg A and B, bone assemblages contain only remains of domestic animals (Brink and Webley 1996; Webley 2007). This shows that in some groups the importance of pastoralist subsistence strategies increased dramatically over time.

The results of the comparison of the different groups of assemblages may be seen to support Sadr's (2003) hypothesis that livestock herding spread to a large degree via diffusion to existing groups of hunter-gatherers, who integrated this strategy into their existing lifeways. However, important obstacles to the spread of livestock via cultural diffusion have been proposed. First, the minimum size of productive herds has been estimated at 60 animals, a number that may be difficult to acquire at one time through trade, in situations where livestock herding groups are not yet well-established in the wider region (e.g., Smith 2008). Second, ideologically, huntergatherers are more egalitarian and emphasise sharing of meat. This precludes effective herd management (e.g., Smith 1990, 2006b, 2008, 2014). Thirdly, the spread of livestock is argued to happen too quickly for indigenous hunter-gatherers to learn complex herding strategies and to learn to avoid environmental pitfalls (Smith 2014). Some of these proposals have been criticised. Viable herds smaller than oft-cited minimum numbers have been observed (Badenhorst 2012; Orton 2015). Also, the spread of food production methods such as livestock herding can happen (archaeologically) very quickly (Jerardino et al. 2014).

The limited impact of the introduction of livestock on the exploitation of wild animals suggests that the development of livestock herding may be influenced by ideological constraints. The rate of herd growth may have been limited by ideological systems based on egalitarianism, which may partly explain the limited economic role that livestock appears to have had in western South Africa. The adoption of livestock as an additional resource in subsistence economies centred on the

Table 11 Results of the post hoc Tamhane test of the significance of the difference in NISP-based heterogeneity values of the different groups of sites

\begin{tabular}{lllll}
\hline & $\begin{array}{l}\text { Coast domestic } \\
\text { animals present }\end{array}$ & $\begin{array}{l}\text { Coast domestic } \\
\text { animals absent }\end{array}$ & $\begin{array}{l}\text { Inland domestic } \\
\text { animals present }\end{array}$ & $\begin{array}{c}\text { Inland domestic } \\
\text { animals absent }\end{array}$ \\
\hline Coast domestic animals present & - & 0.453 & $<0.01$ & $<0.01$ \\
Coast domestic animals absent & 0.453 & - & $<0.01$ & $<0.01$ \\
Inland domestic animals present & $<0.01$ & $<0.01$ & - & 0.963 \\
Inland domestic animals absent & $<0.01$ & $<0.01$ & 0.963 & - \\
\hline
\end{tabular}

Significant differences are highlighted 


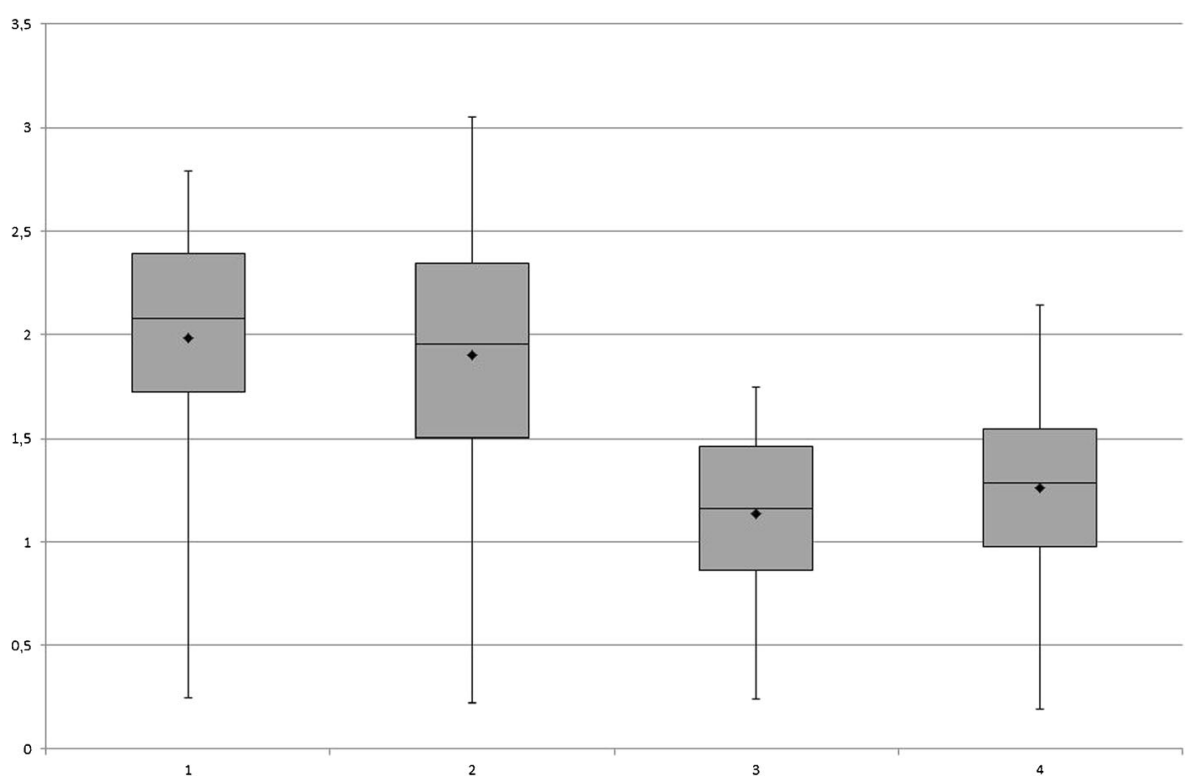

Fig. 9 Box and whisker plots comparing the distribution of $H$ values based on NISP across the four categories of assemblages. Group 1: inland, domestic animals present. Group 2: inland, domestic animals absent. Group 3: coast, domestic animals present. Group 4: coast, domestic animals absent

shellfish exploitation strategies at sites containing sheep bones have been described as intensive at some sites (e.g., Henshilwood 2008; Kyriacou et al. 2015). At Die Kelders, on the other hand, shellfish exploitation intensity is said to decrease after 1500 bp (Henshilwood 2008, p. 149). A detailed comparison of shellfish exploitation is needed to evaluate if, and to what degree, the intensity of shellfish collection changes with the introduction of livestock.

However, other explanations for the lack of changes in diversity of faunal assemblages are also possible. The focus of archaeological research on rockshelters with deeply stratified deposits has been proposed to lead to an underrepresentation of pastoralist sites (Arthur 2008; Smith 2008). This bias towards rockshelter assemblages

Table 12 Results of the post hoc Tamhane test of the significance of the difference in NISP-based evenness values of the different groups of sites

\begin{tabular}{lllll}
\hline & $\begin{array}{l}\text { Coast domestic } \\
\text { animals present }\end{array}$ & $\begin{array}{l}\text { Coast domestic } \\
\text { animals absent }\end{array}$ & $\begin{array}{l}\text { Inland domestic } \\
\text { animals present }\end{array}$ & $\begin{array}{c}\text { Inland domestic } \\
\text { animals absent }\end{array}$ \\
\hline Coast domestic animals present & - & $<0.01$ & $<0.01$ & $<0.01$ \\
Coast domestic animals absent & $<0.01$ & - & $<0.01$ & $<0.01$ \\
Inland domestic animals present & $<0.01$ & $<0.01$ & - & 0.999 \\
Inland domestic animals absent & $<0.01$ & $<0.01$ & 0.999 & - \\
\hline
\end{tabular}

Significant differences are highlighted 


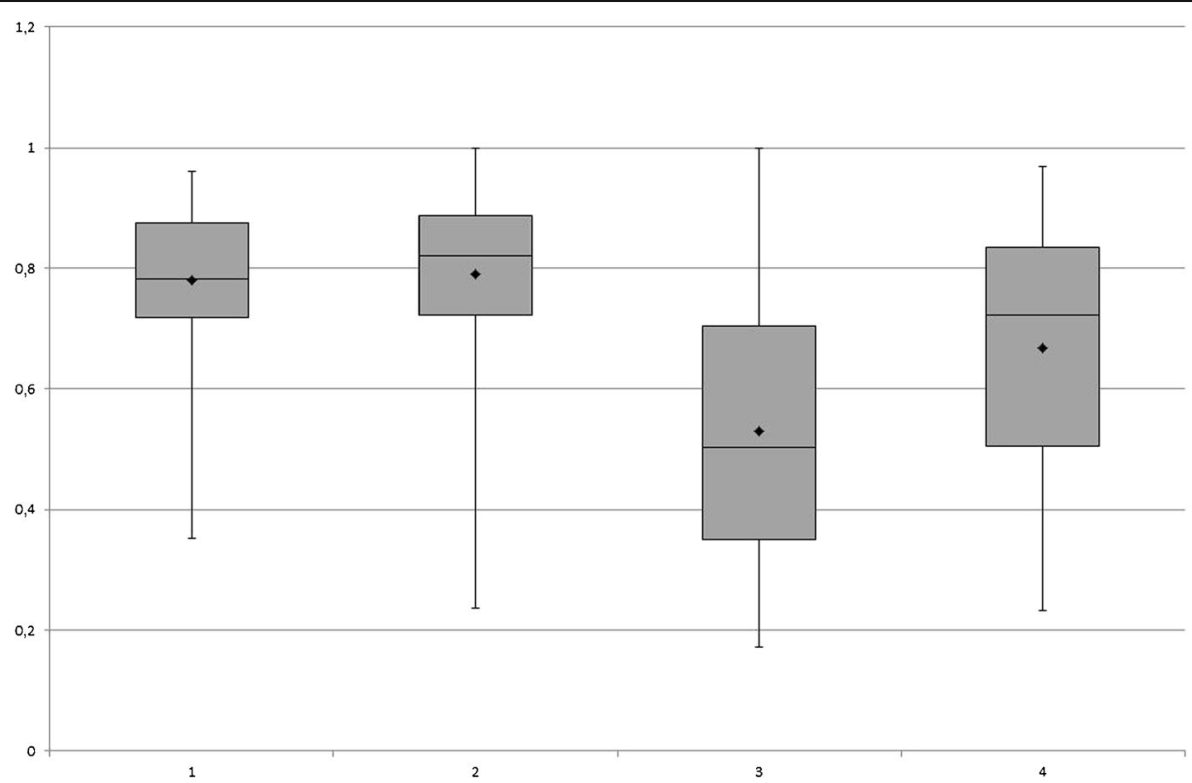

Fig. 10 Box and whisker plots comparing the distribution of $e$ values based on NISP across the four categories of assemblages. Group 1: inland, domestic animals present. Group 2: inland,

may be inherent to a focus on animal remains, as rockshelters are more likely to contain preserved bone remains than open-air sites. Unfortunately, they are less likely to contain pastoralist occupations (Smith 2008). Hence, most of the sites with remains of domestic domestic animals absent. Group 3: coast, domestic animals present. Group 4: coast, domestic animals absent

animals included in the database may represent sites accumulated by hunter-gatherers with access to domestic stock, through processes such as trade or theft. This hypothesis could be supported by the fact that there appears to be no difference in richness of assemblages

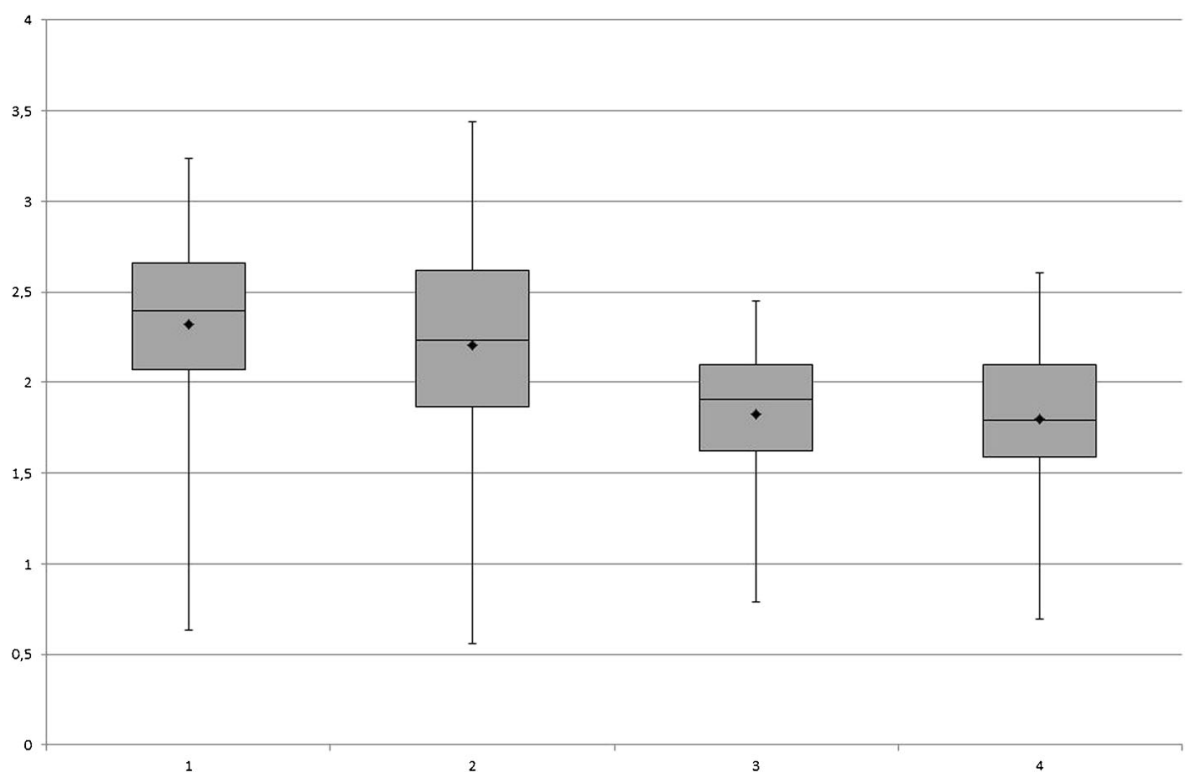

Fig. 11 Box and whisker plots comparing the distribution of $H$ values based on MNI across the four categories of assemblages. Group 1: inland, domestic animals present. Group 2: inland, domestic animals absent. Group 3: coast, domestic animals present. Group 4: coast, domestic animals absent 
Table 13 Results of the one-way ANOVA comparison of the $H$ and $e$ values based on MNI of the four groups of sites

\begin{tabular}{|c|c|c|c|c|c|c|}
\hline & Number & Mean & Standard deviation & $F$ statistic & Significance & Effect size \\
\hline \multicolumn{7}{|l|}{ Heterogeneity } \\
\hline $\begin{array}{l}\text { Coast domestic animals present } \\
\text { Coast domestic animals absent }\end{array}$ & $\begin{array}{l}73 \\
77\end{array}$ & $\begin{array}{l}1.828 \\
1.8011\end{array}$ & $\begin{array}{l}0.377 \\
0.421\end{array}$ & 20,842 & $<0.01$ & 0.151203 \\
\hline Inland domestic animals present & 47 & 2.318 & 0.586 & & & \\
\hline Inland domestic animals absent & 158 & 2.206 & 0.553 & & & \\
\hline \multicolumn{7}{|l|}{ Evenness } \\
\hline $\begin{array}{l}\text { Coast domestic animals present } \\
\text { Coast domestic animals absent }\end{array}$ & $\begin{array}{l}73 \\
77\end{array}$ & $\begin{array}{l}0.83 \\
0.895\end{array}$ & $\begin{array}{l}0.165 \\
0.149\end{array}$ & 12,728 & $<0.01$ & 0.098113 \\
\hline Inland domestic animals present & 47 & 0.923 & 0.089 & & & \\
\hline Inland domestic animals absent & 158 & 0.928 & 0.068 & & & \\
\hline
\end{tabular}

with remains of domestic animals and assemblages $<2000$ bp without remains of domestic animals. Some pastoralist assemblages (e.g., Kasteelberg B) are already included in the database. However, they may be "statistically swamped" by the large number of rockshelters in the assemblage. Nevertheless, the comparison of the (admittedly limited) sample of coastal open-air sites with and without remains of domestic animals does not substantiate this. A number of unpublished assemblages containing large proportions of livestock bones are referred to in the literature (e.g., Sadr 2008). It is possible that their inclusion in the database would alter the outcome of the statistical comparisons.

The hypothesised near-total invisibility of the societies tending livestock appears unlikely for several reasons. First, the access of hunter-gatherers to livestock via trade/ exchange or theft would also be expected to lead to changes in the organisation of foraging strategies, although the ease of access would determine to what degree. The comparison of assemblages with domestic animals and those dated to $>2000$ bp shows no significant changes. If the assemblages with remains of domestic animals were mainly accumulated by hunter-gatherers, this implies that their access to domestic animals was rare. This would suggest very infrequent interactions between different societies living very close to each other.

Second, mtDNA analysis of KhoeSan descendants suggests that a major increase in population size took place during the last 2000 years. This increase has been linked to the increased reproductive success of livestockkeeping societies (Schlebusch et al. 2012). Stable isotope analysis of skeletons radiocarbon-dated to between 2000 and 380 bp demonstrates similarity in diets between pre2000-bp hunter-gatherers and people from the first millennium AD. However, the importance of marine foods does appear to diminish during the first millennium $\mathrm{AD}$ (Sealy 2010). Skeletons dated to the second millennium show a range that partly overlaps with that of earlier hunter-gatherers, but some individuals show an increased reliance on $\mathrm{C}_{4}$-based terrestrial plant foods. This means that people either consumed grassy vegetation or animal products of grazing species. This has been interpreted as signifying the increased importance of cattle meat or milk products in the diet (Sealy 2010).

Table 14 Results of the post hoc Tamhane test of the significance of the difference in MNI-based heterogeneity values of the different groups of sites

\begin{tabular}{lllll}
\hline & $\begin{array}{l}\text { Coast domestic } \\
\text { animals present }\end{array}$ & $\begin{array}{l}\text { Coast domestic } \\
\text { animals absent }\end{array}$ & $\begin{array}{l}\text { Inland domestic } \\
\text { animals present }\end{array}$ & $\begin{array}{l}\text { Inland domestic } \\
\text { animals absent }\end{array}$ \\
\hline Coast domestic animals present & - & 0.999 & $<0.01$ & $<0.01$ \\
Coast domestic animals absent & 0.999 & - & $<0.01$ & $<0.01$ \\
Inland domestic animals present & $<0.01$ & $<0.01$ & - & 0.819 \\
Inland domestic animals absent & $<0.01$ & $<0.01$ & 0.819 & - \\
\hline
\end{tabular}

Significant differences are highlighted 
Table 15 Results of the post hoc Tamhane test of the significance of the difference in MNI-based evenness values of the different groups of sites

\begin{tabular}{lllll}
\hline & $\begin{array}{l}\text { Coast domestic } \\
\text { animals present }\end{array}$ & $\begin{array}{l}\text { Coast domestic } \\
\text { animals absent }\end{array}$ & $\begin{array}{c}\text { Inland domestic } \\
\text { animals present }\end{array}$ & $\begin{array}{c}\text { Inland domestic } \\
\text { animals absent }\end{array}$ \\
\hline Coast domestic animals present & - & 0.075 & $<0.01$ & $<0.01$ \\
Coast domestic animals absent & 0.075 & - & 0.679 & 0.323 \\
Inland domestic animals present & $<0.01$ & 0.679 & - & 1 \\
Inland domestic animals absent & $<0.01$ & 0.323 & - & 1 \\
\hline
\end{tabular}

Significant differences are highlighted

It may be hypothesised that in the first millennium $\mathrm{AD}$, increases in the reliability of the food supply associated with herding raised the Malthusian ceiling. To feed the larger populations, hunting and gathering remained important. This is supported by the stable isotope evidence. One of the ways in which herding may have complemented hunting and gathering is by providing a reliable fall-back food during periods where wild resources were scarce. This might have beneficial effects on the prevention of (especially child) mortality, leading to a population increase, even though the total caloric contribution of herding may not have been great. This may be supported by the fact that average human femur length appears to increase after $2000 \mathrm{bp}$, which suggests better nutrition (Sealy and Pfeiffer 2000; Ginter 2008). Moreover, the investment in livestock herding may have come partly from women or children and, as such, may not be completely reflected in the exploitation of wild mammals.

\section{Conclusion}

This analysis suggests that in LSA societies in South Africa, livestock initially functioned in a system in which groups practised a mixed economy, with an important role for wild-food foraging. Although the model focuses solely on the economic importance of livestock, it does not imply that increased reliability of the food supply was the main reason for the initial adoption of herding. Alternative options, such as the suggestion that it played a role in feasting (cf. Sadr 2004), remain a possibility. Nevertheless, the adoption of livestock

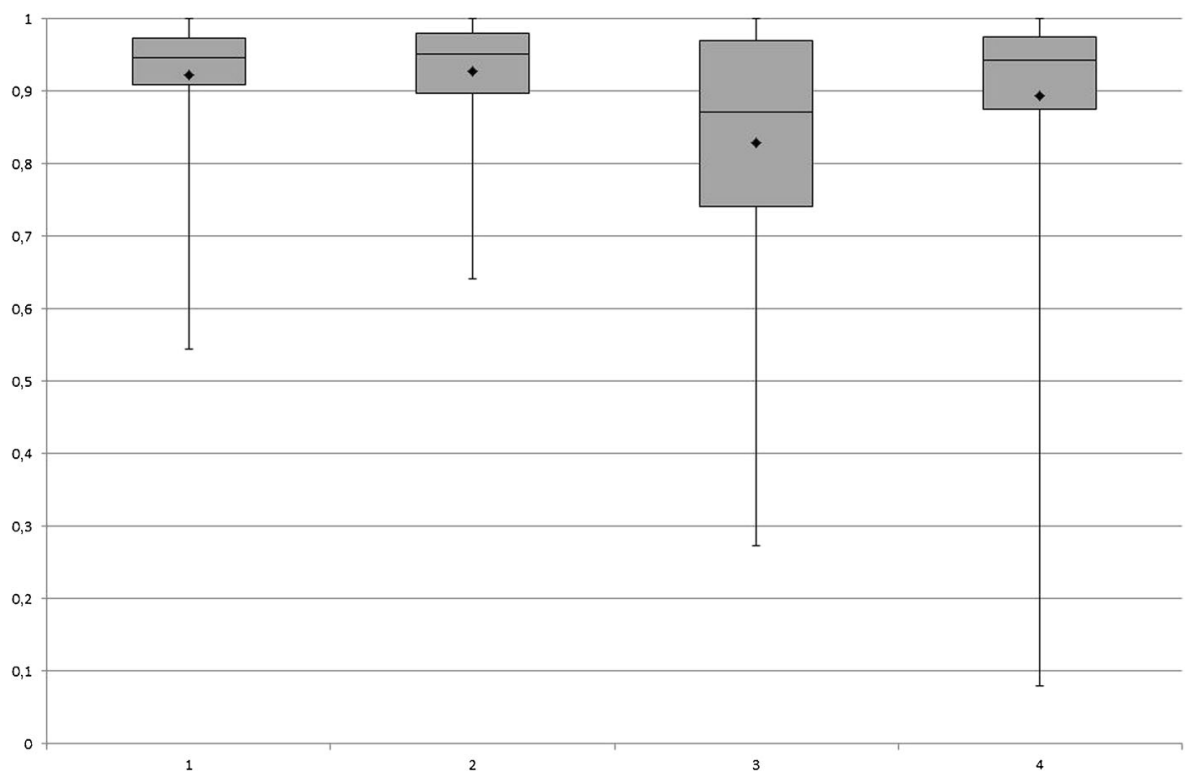

Fig. 12 Box and whisker plots comparing the distribution of $e$ values based on MNI across the four categories of assemblages. Group 1: inland, domestic animals present. Group 2: inland, domestic animals absent. Group 3: coast, domestic animals present. Group 4: coast, domestic animals absent 
herding did have economic effects that can be studied. It is likely that the increased security of the food supply led to the increase in population size that is apparent genetically. When larger populations are established and herd size does not increase quickly, foraging for wild resources remains important. A larger population can explain the apparent paradox that marine resources decrease in importance in the diet as seen through stable isotopes, but the importance of wild and especially marine resources remains large in the excavated assemblages. The ideology of hunter-gatherer groups adopting livestock may have influenced the tempo of increase in herd size and thus limited the economic importance of livestock herding. Future research of dated assemblages may clarify whether the increased investment in livestock herding is reflected more in a change in gathering strategies. Also, the increased importance of livestock herding through time can be clarified by subdividing dated faunal assemblages in different time categories.

Acknowledgments I would like to thank Annie Antonites, Karin Scott and Evin Grody for inviting me to contribute to this special issue. I thank Francis Thackeray for making available information that was in press at the time of writing. Luc Amkreutz, Welmoed Out, Judy Sealy and Annemarieke Willemsen helped in tracking down literature. Richard Devey of the Statistical Consultation Service at the University of Johannesburg is thanked for assistance with statistical procedures. I also want to thank the anonymous reviewers, whose suggestions greatly improved the paper.

Compliance with Ethical Standards This work was supported by the University of Johannesburg Research Committee and the South African National Research Foundation-funded MicroTrACKS programme, directed by Prof. M. Lombard. The author declares no conflict of interest.

Open Access This article is distributed under the terms of the Creative Commons Attribution 4.0 International License (http:// creativecommons.org/licenses/by/4.0/), which permits unrestricted use, distribution, and reproduction in any medium, provided you give appropriate credit to the original author(s) and the source, provide a link to the Creative Commons license, and indicate if changes were made.

\section{References}

Alvard, M. S., \& Kuznar, L. (2001). Deferred harvests: The transition from hunting to animal husbandry. American Anthropologist, 103(2), 295-311.

Arthur, C. (2008). The archaeology of indigenous herders in the Western Cape of South Africa. Southern African Humanities, 20, 205-220.
Backwell, L., Bhagwandas-Jogibhai, K., Fenn, G., James, C., Laue, G., Matier, J., \& Wallace, C. (1996). Twyfelpoort shelter: A Later Stone Age sequence. Southern African Field Archaeology, 5(2), 84-95.

Badenhorst, S. (2003). The archaeofauna from iNkolimahashi shelter, a Later Stone Age shelter in the Thukela Basin, KwaZulu-Natal, South Africa. Southern African Humanities, 15, 45-57.

Badenhorst, S. (2012). The significance of bone numbers in Iron Age faunal studies from Southern Africa: A reply to Huffman. South African Archaeological Bulletin, 67(196), 264-267.

Binneman, J. (1997). Results from a test excavation at The Havens Cave, Cambria Valley, south-eastern Cape. Southern African Field Archaeology, 6(2), 93-105.

Binneman, J. (2000). Results from two test excavations in the Baviaanskloof Mountains, Eastern Cape Province. Southern African Field Archaeology, 9, 83-96.

Binneman, J. (2006/2007). Archaeological research along the South-Eastern Cape coast part 2, caves and shelters: Kabeljous River Shelter 1 and associated stone tool industries. Southern African Field Archaeology, 15-16, 57-74.

Brink, J. (2012). Appendix: The fauna from Lithakong. Southern African Humanities, 24, 30-32.

Brink, J., \& Webley, L. (1996). Faunal evidence for pastoralist settlement at Jakkalsberg, Richtersveld, Northern Cape Province. Southern African Field Archaeology, 5(2), 70-78.

Cable, J. H. C., Scott, K., \& Carter, P. L. (1980). Excavations at Good Hope Shelter, Underberg District, Natal. Annals of the Natal Museum, 24(1), 1-34.

Cruz-Uribe, K. (1988). The use and meaning of species diversity and richness in archaeological faunas. Journal of Archaeological Science, 15, 179-196.

Deacon, H. J. (1976). Where hunters gathered: A study of Holocene Stone Age people in the Eastern Cape. Claremont: South African Archaeological Society.

Dewar, G. I. (2008). The archaeology of the coastal desert of Namaqualand, South Africa: A regional synthesis. Oxford: Archaeopress.

Dewar, G., Halkett, D., Hart, T., Orton, J., \& Sealy, J. (2006). Implications of a mass kill site of springbok (Antidorcas marsupialis) in South Africa: Hunting practices, gender relations, and sharing in the Later Stone Age. Journal of Archaeological Science, 33(9), 1266-1275.

Domínguez-Rodrigo, M. (2012). Critical review of the MNI (minimum number of individuals) as a zooarchaeological unit of quantification. Archaeological and Anthropological Sciences, 4(1), 47-59.

Dusseldorp, G. L. (2012a). Studying prehistoric hunting proficiency: Applying Optimal Foraging Theory to the Middle Palaeolithic and Middle Stone Age. Quaternary International, 252, 3-15.

Dusseldorp, G. L. (2012b). Tracking the influence of Middle Stone Age technological change on modern human hunting strategies. Quaternary International, 270, 70-79.

Dusseldorp, G. L., \& Langejans, G. H. J. (2013). Carry that weight: Coastal foraging and transport of marine resources during the South African Middle Stone Age. Southern African Humanities, 25, 105-135.

Faith, J. T. (2008). Eland, buffalo, and wild pigs: Were Middle Stone Age humans ineffective hunters? Journal of Human Evolution, 55(1), 24-36. 
Faith, J. T. (2011). Ungulate community richness, grazer extinctions, and human subsistence behavior in southern Africa's Cape Floral Region. Paleogeography, Palaeoclimatology, Palaeoecology, 306, 219-227.

Faith, J. T. (2013). Taphonomic and paleoecological change in the large mammal sequence from Boomplaas Cave, Western Cape, South Africa. Journal of Human Evolution, 65, 715730 .

Ginter, J. K. (2008). A bioarchaeological study of mid-Holocene communities in the Eastern Cape, South Africa: The interface between foraging and pastoralism. PhD Dissertation, University of Toronto.

Grayson, D. K. (1991). Alpine faunas from the White Mountains, California: Adaptive change in the late prehistoric great basin? Journal of Archaeological Science, 18(4), 483-506.

Grayson, D. K., \& Delpech, F. (1998). Changing diet breadth in the Early Upper Palaeolithic of southwestern France. Journal of Archaeological Science, 25(11), 1119-1129.

Gremillion, K. J. (1996). Diffusion and adoption of crops in evolutionary perspective. Journal of Anthropological Archaeology, 15(2), 183-204.

Gurven, M., \& Kaplan, H. (2006). Determinants of time allocation across the lifespan: A theoretical model and an application to the Machiguenga and Piro of Peru. Human Nature, 17, 1-49.

Henshilwood, C. S. (2008). Holocene archaeology of the coastal Garcia State Forest, Southern Cape, South Africa. Oxford: Archaeopress.

Hobart, J. (2004). Pitsaneng: Evidence for a Neolithic Lesotho. Before Farming, 4, Article 4.

Ingold, T. (2000). The optimal forager and the economic man. In T. Ingold (Ed.), The perception of the environment: Essays on livelihood, dwelling and skill (pp. 27-39). London: Routledge.

Inskeep, R. R. (1987). Nelson Bay Cave, Cape Province, South Africa: The Holocene levels. Oxford: British Archaeological Reports.

Jerardino, A. (2007). Excavations at a hunter-gatherer site known as 'Grootrif G' Shell Midden, Lamberts Bay, Western Cape Province. South African Archaeological Bulletin, 62(186), 162-170.

Jerardino, A. (2010). Prehistoric exploitation of marine resources in southern Africa with particular reference to shellfish gathering: Opportunities and continuities. Pyrenae, 41(1), 7-52.

Jerardino, A. (2012). Large shell middens and hunter-gatherer resource intensification along the West Coast of South Africa: The Elands Bay case study. Journal of Island and Coastal Archaeology, 7(1), 76-101.

Jerardino, A., \& Yates, R. (1996). Preliminary results from excavations at Steenbokfontein Cave: Implications for past and future research. South African Archaeological Bulletin, 51(163), 7-16.

Jerardino, A., Fort, J., Isern, N., \& Rondelli, B. (2014). Cultural diffusion was the main driving mechanism of the Neolithic transition in southern Africa. PloS One, 9(12), e113672.

Jerardino, A., Horwitz, L. K., Mazel, A., \& Navarro, R. (2009). Just before Van Riebeeck: Glimpses into terminal LSA lifestyle at Connies Limpet Bar, West coast of South Africa. South African Archaeological Bulletin, 64(189), 75-86.

Johnson, A. L. (2014). Exploring adaptive variation among hunter-gatherers with Binford's frames of reference. Journal of Archaeological Research, 22(1), 1-42.
Jones, E. L. (2004). Dietary evenness, prey choice and humanenvironment interactions. Journal of Archaeological Science, 31(3), 307-317.

Kandel, A. W., \& Conard, N. J. (2003). Scavenging and processing of whale meat and blubber by Later Stone Age people of the Geelbek Dunes, Western Cape Province, South Africa. South African Archaeological Bulletin, 58(178), 91-93.

Kaplan, J. (1987). Settlement and subsistence at Renbaan Cave. In J. Parkington \& M. Hall (Eds.), Papers in the prehistory of the Western Cape, South Africa (pp. 350-371). Oxford: British Archaeological Reports.

Kelly, R. L. (1995). The foraging spectrum: Diversity in huntergatherer lifeways. Washington: Smithsonian Institution Press.

Klein, R. G. (1976). The mammalian fauna of the Klasies River Mouth Sites, Southern Cape Province, South Africa. South African Archaeological Bulletin, 31(123/124), 75-98.

Klein, R. G. (1978a). A preliminary report on the larger mammals from the Boomplaas Stone Age Cave Site, Cango Valley, Oudtshoorn District, South Africa. South African Archaeological Bulletin, 33(127), 66-75.

Klein, R. G. (1978b). The vertebrate fauna from the Buffelskloof rockshelter. Appendix of excavations in the Buffelskloof Shelter near Calitzdorp. Southern Cape. South African Archaeological Bulletin, 33(127), 35-38.

Klein, R. G. (1979). Paleoenvironmental and cultural implications of Late Holocene archaeological faunas from the Orange Free State and North-Central Cape Province, South Africa. South African Archaeological Bulletin, 34(129), 34-49.

Klein, R. G. (1986). The prehistory of Stone Age herders in the Cape province of South Africa. Goodwin Series, 5, 5-12.

Klein, R. G., \& Cruz-Uribe, K. (1987). Large mammal and tortoise bones from Eland's Bay Cave and nearby sites, Western Cape Province, South Africa. In J. Parkington \& M. Hall (Eds.), Papers in the prehistory of the Western Cape, South Africa (pp. 132-163). Oxford: British Archaeological Reports.

Klein, R. G., \& Cruz-Uribe, K. (1989). Faunal evidence for prehistoric herder-forager activities at Kasteelberg, Western Cape Province, South Africa. South African Archaeological Bulletin, 44(150), 82-97.

Klein, R. G., \& Cruz-Uribe, K. (2000). Middle and Later Stone Age large mammal and tortoise remains from Die Kelders Cave 1, Western Cape Province, South Africa. Journal of Human Evolution, 38(1), 169-195.

Klein, R. G., Cruz-Uribe, K., \& Beaumont, P. B. (1991). Environmental, ecological, and paleoanthropological implications of the late Pleistocene mammalian fauna from Equus Cave, northern Cape Province, South Africa. Quaternary Research, 36(1), 94-119.

Korsman, S., \& Plug, I. (1994). Two Later Stone Age sites on the farm Honingklip in the Eastern Transvaal. South African Archaeological Bulletin, 49(159), 24-32.

Kyriacou, K., Parkington, J. E., Marais, A. D., \& Braun, D. R. (2014). Nutrition, modernity and the archaeological record: Coastal resources and nutrition among Middle Stone Age hunter-gatherers on the western Cape coast of South Africa. Journal of Human Evolution, 77, 64-73.

Kyriacou, K., Parkington, J., Will, M., Kandel, A. W., \& Conard, N. J. (2015). Middle and Later Stone Age shellfish exploitation strategies and coastal foraging at Hoedjiespunt and Lynch Point, Saldanha Bay, South Africa. Journal of Archaeological Science, 57, 197-206. 
Lesur, J., Hildebrand, E. A., Abawa, G., \& Gutherz, X. (2014). The advent of herding in the Horn of Africa: New data from Ethiopia, Djibouti and Somaliland. Quaternary International, 343, 148-158.

Lombard, M., \& Parsons, I. (2015). Milk not meat: The role of milk amongst the Khoe peoples of southern Africa. Journal of Anthropological Archaeology, 13(2), 149-166.

Lombard, M., Wadley, L., Deacon, J., Wurz, S., Parsons, I., Mohapi, M., Swart, J., \& Mitchell, P. (2012). South African and Lesotho Stone Age sequence updated. South African Archaeological Bulletin, 67(195), 123-144.

Louwe Kooijmans, L. P. (1993). Wetland exploitation and upland relations of prehistoric communities in the Netherlands. In J. Gardiner (Ed.), Flatlands and wetlands: Current themes in East Anglian archaeology (pp. 71-116). Norwich: Scole Archaeological Committee.

Lyman, R. L. (2008). Quantitative paleozoology. Cambridge: Cambridge University Press.

Lyman, R. L. (2015). On the variable relationship between NISP and NTAXA in bird remains and in mammal remains. Journal of Archaeological Science, 53, 291-296.

MacArthur, R. H., \& Pianka, E. R. (1966). On optimal use of a patchy environment. American Naturalist, 100(916), 603609.

Marean, C. W. (1985). The faunal remains from Smitswinkelbaai Cave, Cape peninsula. South African Archaeological Bulletin, 40(145), 100-102.

Marean, C. W. (2010). Pinnacle Point Cave 13B (Western Cape Province, South Africa) in context: The Cape Floral kingdom, shellfish, and modern human origins. Journal of Human Evolution, 59(3-4), 425-443.

Marlowe, F. W. (2007). Hunting and gathering: The human sexual division of foraging labor. Cross-Cultural Research, 41(2), 170-195.

Mazel, A. D. (1984a). Diamond 1 and Clarke's Shelter: Report on excavations in the northern Drakensberg, Natal, South Africa. Annals of the Natal Museum, 26(1), 25-70.

Mazel, A. D. (1984b). Gehle Shelter: Report on excavations in the uplands ecological zone, Tugela Basin, Natal, South Africa. Annals of the Natal Museum, 26(1), 1-24.

Mazel, A. D. (1986a). Mbabane Shelter and eSinhlonhlweni Shelter: The last two thousand years of hunter-gatherer settlement in the central Thukela Basin, Natal, South Africa. Annals of the Natal Museum, 27(2), 386-453.

Mazel, A. D. (1986b). Mgede Shelter: A mid- and late Holocene observation in the western Biggarsberg, Thukela Basin, Natal, South Africa. Annals of the Natal Museum, 27(2), 357-387.

Mazel, A. D. (1988). Nkupe Shelter: Report on excavations in the eastern Biggarsberg, Thukela Basin, Natal, South Africa. Annals of the Natal Museum, 29(2), 321-377.

Mazel, A. D. (1990). Mhlwazini Cave: The excavation of late Holocene deposits in the northern Natal Drakensberg, Natal, South Africa. Natal Museum Journal of Humanities, 2, 95-133.

Mazel, A. D. (1992). Collingham Shelter: The excavation of Late Holocene deposits, Natal, South Africa. Natal Museum Journal of Humanities, 4, 1-51.

Mazel, A. D. (1993). KwaThwaleyakhe Shelter: The excavation of mid and later Holocene deposits in the central Thukela Basin,
Natal, South Africa. Natal Museum Journal of Humanities, 5 , $1-36$.

Mazel, A. D. (1996). Maqonqo Shelter: The excavation of Holocene deposits in the eastern Biggarsberg, Thukela Basin, South Africa. Natal Museum Journal of Humanities, 8, 1-39.

McGuire, K. R., \& Hildebrandt, W. R. (2005). Re-thinking Great Basin foragers: Prestige hunting and costly signaling during the Middle Archaic Period. American Antiquity, 70(4), 695712.

Meltzer, D. J., Leonard, R. D., \& Stratton, S. K. (1992). The relationship between sample size and diversity in archaeological assemblages. Journal of Archaeological Science, 19(4), 375-387.

Mitchell, P. J. (1993). The archaeology of Tloutle rock-shelter, Maseru District, Lesotho. Navorsinge van die Nasionale Museum Bloemfontein, 9, 77-132.

Morris, A. G., Heinze, A., Chan, E. K. F., Smith, A. B., \& Hayes, V. M. (2014). First ancient mitochondrial human genomen from a prepastoralist southern African. Genome Biology and Evolution, 6(10), 2647-2653.

Murdock, G. P., \& Provost, C. (1973). Factors in the division of labor by sex: A cross-cultural analysis. Ethnology, 12(2), 203-225.

Noli, D. (1988). Results of the 1986 excavation at Hailstone Midden (HSM), Eland's Bay, Western Cape Province. South African Archaeological Bulletin, 43(147), 43-48.

Opperman, H. (1987). The Later Stone Age of the Drakensberg Range and its foothills. Oxford: British Archaeological Reports.

Orton, J. (2012). Late Holocene archaeology in Namaqualand, South Africa: Hunter-gatherers and herders in a semi-arid environment. PhD Dissertation, Oxford University.

Orton, J. (2014). The late pre-colonial site of Komkans 2 (KK002) and an evaluation of the evidence for indigenous copper smelting in Namaqualand, southern Africa. Azania, 49(3), $386-410$.

Orton, J. (2015). The introduction of pastoralism to southernmost Africa: Thoughts on new contributions to an ongoing debate. Azania, 50(2), 250-258.

Orton, J., Klein, R. G., Mackay, A., Schwortz, S., \& Steele, T. E. (2011). Two Holocene rock shelter deposits from the Knersvlakte, southern Namaqualand, South Africa. Southern African Humanities, 23, 109-150.

Parkington, J., \& Poggenpoel, C. (1971). Excavations at De Hangen, 1968. South African Archaeological Bulletin, 26(101/102), 3-36.

Pleurdeau, D., Imalwa, E., Détroit, F., Lesur, J., Veldman, A., Bahain, J.-J., \& Marais, E. (2012). "Of sheep and men" Earliest evidence of caprine domestication in southern Africa at Leopard Cave (Erongo, Namibia). PloS One, 7(7), e40340.

Plug, I. (1996). The hunter's choice: Faunal remains from Maqonqo Shelter. Natal Museum Journal of Humanities, 8, 41-52.

Plug, I. (1997). Late Pleistocene and Holocene hunter-gatherers in the eastern highlands of South Africa and Lesotho: A faunal interpretation. Journal of Archaeological Science, 24(8), 715-727. 
Plug, I. (2002). Faunal remains from Mzinyashana, a Later Stone Age site in KwaZulu-Natal, South Africa. Southern African Humanities, 14, 51-63.

Plug, I., \& Engela, R. (1992). The macrofaunal remains from recent excavations at Rose Cottage Cave, Orange Free State. South African Archaeological Bulletin, 47, 16-25.

Plug, I., \& Mitchell, P. (2008). Sehonghong: Hunter-gatherer utilization of animal resources in the highlands of Lesotho. Annals of the Transvaal Museum, 45, 31-53.

Plug, C., \& Plug, I. (1990). MNI counts as estimates of species abundance. South African Archaeological Bulletin, 45, 5357.

Plug, I., Mitchell, P., \& Bailey, G. (2003). Animal remains from Likoaeng, an open-air river site, and its place in the post-classic Wilton of Lesotho and eastern Free State, South Africa. South African Journal of Science, 99, 143-152.

Plug, I., Mitchell, P., \& Bailey, G. (2010). Late Holocene fishing strategies in southern Africa as seen from Likoaeng, highland Lesotho. Journal of Archaeological Science, 37, 3111-3123.

Robbins, L. H., Campbell, A., Murphy, M. L., Brook, G. A., Srivastava, P., \& Badenhorst, S. C. (2005). The advent of herding in Southern Africa: Early AMS dates on domestic livestock from the Kalahari Desert. Current Anthropology, 46(4), 671-677.

Robertshaw, P. T. (1975-1977). Archaeological investigations at Langebaan Lagoon, Cape Province. Palaeoecology of Africa, 10, 139-148.

Sadr, K. (2003). The Neolithic of southern Africa. The Journal of African History, 44(2), 195-209.

Sadr, K. (2004). Feasting on Kasteelberg? Early herders on the West coast of South Africa. Before Farming, 2003/4, Article 2.

Sadr, K. (2008). Invisible herders? The archaeology of Khoekhoe pastoralists. Southern African Humanities, 20, 179-203.

Sadr, K. (2009). Marine shell dates and surface lithic assemblages on the west coast of South Africa. Journal of Archaeological Science, 36(12), 2713-2729.

Sadr, K. (2015). Livestock first reached Southern Africa in two separate events. PloS One, 10(8), e0134215.

Sadr, K., Smith, A., Plug, I., Orton, J., \& Mütti, B. (2003). Herders and foragers on Kasteelberg: Interim report of excavations 1999-2002. South African Archaeological Bulletin, 58(177), 27-32.

Schlebusch, C. M., Skoglund, P., Sjödin, P., Gattepaille, L. M., Hernandez, D., Jay, F., Li, S., De Jongh, M., Singleton, A., Blum, M. G. B., Soodyall, H., \& Jakobsson, M. (2012). Genomic variation in Seven Khoe-San groups reveals adaptation and complex African history. Science, 338(6105), 374-379.

Schweitzer, F. R. (1979). Excavations at Die Kelders, Cape Province. The Holocene deposits. Annals of the South African Museum, 78, 101-223.

Schweitzer, F. R., \& Wilson, M. L. (1982). Byneskranskop 1: A late Quaternary living site in the Southern Cape Province, South Africa. Annals of the South African Museum, 88, 1203.

Sealy, J. (2010). Isotopic evidence of cattle-based pastoralism in southernmost South Africa. Journal of African Archaeology, $8(1), 65-81$.
Sealy, J., \& Pfeiffer, S. (2000). Diet, body size, and landscape use among Holocene people in the Southern Cape, South Africa. Current Anthropology, 41(4), 642-655.

Sealy, J., Maggs, T., Jerardino, A., \& Kaplan, J. (2004). Excavations at Melkbosstrand: Variability among herder sites on Table Bay, South Africa. South African Archaeological Bulletin, 59(179), 17-28.

Smith, A. B. (1990). On becoming herders: Khoikhoi and San ethnicity in Southern Africa. African Studies, 49(2), 51-73.

Smith, A. B. (2006a). Excavations at Kasteelberg and the origins of the Khoekhoen in the Western Cape, South Africa. Oxford: Archaeopress.

Smith, A. B. (2006b). Origins and spread of African pastoralism. History Compass, 4(1), 1-7.

Smith, A. B. (2008). Pastoral origins at the Cape, South Africa: Influences and arguments. Southern African Humanities, 20, 49-60.

Smith, A. B. (2014). The origins of herding in Southern Africa: Debating the 'Neolithic' model. Saarbrücken: Lambert Academic Publishing.

Smith, A. B., \& Kinahan, J. (1984). The invisible whale. World Archaeology, 16, 89-97.

Smith, A. B., \& Webley, L. (2000). Women \& men of the Khoekhoen of southern Africa. In D. L. Hodgson (Ed.), Rethinking pastoralism in Africa: Gender, culture \& the myth of the patriarchal pastoralist (pp. 72-96). Oxford: James Currey.

Smith, A. B., Halkett, D., Hart, T., \& Mütti, B. (2001). Spatial patterning, cultural identity and site integrity on open sites: Evidence from Bloeddrift 23, a pre-colonial herder camp in the Richtersveld, Northern Cape province. South African Archaeological Bulletin, 56(173/174), 23-33.

Smith, A. B., Sadr, K., Gribble, J., \& Yates, R. (1991). Excavations in the South-Western Cape, South Africa, and the archaeological identity of prehistoric hunter-gatherers within the last 2000 years. South African Archaeological Bulletin, 46(154), 71-91.

Steele, T. E., \& Klein, R. G. (2013). The Middle and Later Stone Age faunal remains from Diepkloof Rock Shelter, Western Cape, South Africa. Journal of Archaeological Science, 40(9), 3453-3462.

Stewart, B. A. (2010). Modifications on the bovid bone assemblage from Dunefield Midden, South Africa: Stage one of a multivariate taphonomic analysis. Azania, 45, 238-275.

Turner, G. (1986). Faunal remains from Jubilee Shelter, Transvaal. South African Archaeological Bulletin, 41(144), 63-68.

Twiss, K. (2012). The archaeology of food and social diversity. Journal of Archaeological Research, 20(4), 357-395.

Van Rijssen, W. J., \& Avery, G. (1992). The Late Holocene deposits at Klein Kliphuis Shelter, Cedarberg, Western Cape Province. South African Archaeological Bulletin, 47(155), 34-43.

Wadley, L. (2001). Who lived in Mauermanshoek Shelter, Korannaberg, South Africa? African Archaeological Review, 18(3), 153-179.

Wadley, L., \& Turner, G. (1987). Hope Hill Shelter: A Later Stone Age site in the southern Transvaal. South African Journal of Science, 83, 98-105.

Walker, M. J. C., Berkelhammer, M., Björck, S., Cwynar, L. C., Fisher, D. A., Long, A. J., Lowe, J. J., Newnham, R. M., Rasmussen, S. O., \& Weiss, H. (2012). Formal subdivision of 
the Holocene Series/Epoch: A discussion paper by a working group of INTIMATE (Integration of ice-core, marine and terrestrial records) and the Subcommission on Quaternary Stratigraphy (International Commission on Stratigraphy). Journal of Quaternary Science, 27(7), 649-659.

Webley, L. (1992). Early evidence for sheep from Spoeg River Cave, Namaqualand. Southern African Field Archaeology, 1(1), 3-13.

Webley, L. (2007). Archaeological evidence for pastoralist landuse and settlement in Namaqualand over the last 2000 years. Journal of Arid Environments, 70(4), 629-640.

Wilkie, D. S., \& Curran, B. (1993). Historical trends in forager and farmer exchange in the Ituri rain forest of northeastern Zaïre. Human Ecology, 21(4), 389-417.

Winterhalder, B. (1987). The analysis of hunter-gatherer diets: Stalking an optimal foraging model. In M. Harris \& E. B. Ross (Eds.),
Food and evolution, toward a theory of human food habits (pp. 311-341). Philadelphia: Temple University Press.

Winterhalder, B. (2001). The behavioural ecology of huntergatherers. In C. Panter-Brick, R. H. Layton, \& P. Rowley-Conwy (Eds.), Hunter-gatherers, an interdisciplinary perspective (pp. 12-38). Cambridge: Cambridge University Press.

Yellen, J. (1984). The integration of herding into prehistoric hunting and gathering economies. In M. Hall, G. Avery, D. M. Avery, M. L. Wilson, \& A. J. B. Humphreys (Eds.), Frontiers: Southern African archaeology today (pp. 53-64). Oxford: British Archaeological Reports.

Zeder, M. (2012). The broad spectrum revolution at 40: Resource diversity, intensification and an alternative to optimal foraging explanations. Journal of Anthropological Archaeology, 31, 241-264. 